\title{
1 Unraveling the stepwise maturation of the yeast telomerase
}

3

4 Anna Greta Hirsch ${ }^{1}$, Daniel Becker ${ }^{2}$, Jan-Philipp Lamping ${ }^{1}$ and Heike

5 Krebber $^{1 *}$

6

$7 \quad{ }^{1}$ Abteilung für Molekulare Genetik, Institut für Mikrobiologie und Genetik, Göttinger

8 Zentrum für Molekulare Biowissenschaften (GZMB), Georg-August Universität Göttingen,

9 Göttingen, Germany

$10{ }^{2}$ Current address: Philipps-Universität Marburg, Klinik für Dermatologie und Allergologie,

11 Baldingerstraße, D-35043 Marburg

12

$13 \quad{ }^{*}$ Correspondence: heike.krebber@biologie.uni-goettingen.de

19 Short title: Required order for telomerase maturation

21 Keywords: Telomerase / Telomere maintenance / non-coding RNA / snRNA maturation /

22 nucleo-cytoplasmic compartmentalization 


\section{Abstract}

24 Telomerases elongate the ends of chromosomes required for cell immortality

25 through their reverse transcriptase activity. By using the model organism

26 Saccharomyces cerevisiae we defined the order in which the holoenzyme 27 matures. First, a longer precursor of the telomerase RNA, TLC1 is transcribed 28 and exported into the cytoplasm, where it associates with the protecting Sm29 ring, the Est- and the Pop-proteins. This partly matured telomerase is re-import

30 into the nucleus via Mtr10 and a novel $T L C 1$-import factor, the karyopherin

31 Cse1. Remarkably, while mutations in all known transport factors result in 32 short telomere ends, mutation in CSE1 bypasses this defect and become Type I 33 like survivors. Interestingly, both import receptors contact the Sm-ring for 34 nuclear import, which therefore resembles a quality control step in the 35 maturation process of the telomerase. The re-imported immature $T L C 1$ is finally 36 trimmed into the $\sim \mathbf{1 1 5 0}$ nucleotide long mature form. TMG-capping of $T L C 1$ 37 finalizes maturation, leading to mature telomerase. 


\section{Introduction}

40 The protection and maintenance of the ends of linear chromosomes during replication

41 is crucial for dividing eukaryotic cells. Therefore, nucleoprotein structures called

42 telomeres shield the ends of linear chromosomes from double strand break repair

43 activities and thus from end-to-end ligations that would cause massive genome

44 rearrangements and genome instability ${ }^{1,2}$. These telomeres are the target of a

45 ribonucleoprotein (RNP) complex, called telomerase that protects the chromosome

46 ends from progressive shortening by extending them through its reverse transcriptase

47 activity. While in most somatic cells telomere shortening occurs after sufficient cell

48 divisions and causes a cell to enter into replicative senescence, stem cells, germ cells,

49 lymphocytes and unicellular eukaryotes like yeast express telomerase to encounter

50 this effect. Remarkably, almost $90 \%$ of all cancer cells have re-activated the

51 telomerase activity to bypass their proliferation limit $1,3,4,5$. As the production of

52 functional telomerase is crucial for telomere maintenance, it is important to

53 understand its assembly and the order of its step-wise maturation process to realize

54 the underlying control mechanisms that generate functional telomerase.

The telomerase is an RNP complex that contains a long non-coding RNA component, TLC1 (telomerase component 1) composed of 1158 nucleotides in yeast,

57 which functions as template for the synthetic telomere repeats and as a scaffold for

58 the protein components of the holoenzyme, providing the reverse transcriptase

59 activity ${ }^{2,6,7,8}$ Like mRNAs and most lncRNAs, TLC1 is transcribed in the nucleus

60 by RNA polymerase II (RNAP II) and it is subsequently capped with a monomethyl

61 guanosine $\left(\mathrm{m}^{7} \mathrm{G}\right)$ cap and polyadenylated like mRNAs ${ }^{6,9}$. However, in contrast to

62 mRNAs, but very similar to the snRNAs, Tgs 1 generates a 2,2,7-trimethylguanosine

63 (TMG)-cap on TLC1 in the nucleolus, which persists in the mature telomerase ${ }^{6,10,11}$. 
64 Interestingly, TLC1 was described to exist in two forms in the cell, an 1158

65 nucleotide long mature form and a $\sim 1300$ nucleotide long precursor. The majority of

66 the TLC1 molecules that are present in cells is the short form and only $\sim 10 \%$ of the

67 TLC1 RNA is the long polyadenylated form ${ }^{12}$. This might reflect that approximately

$6810 \%$ of the TLC1 RNAs might be in their maturation phase and $90 \%$ are already

69 matured. However, in addition to the polyadenylation factor mediated transcription

70 termination (CPF-CF), as used for mRNAs, a study uncovered the ability of the

71 Nrd1-Nab3-Sen1 (NNS) system to terminate $T L C 1$ transcription and it was suggested

72 that this would immediately generate the $\sim 1150$ nucleotides short form, characteristic

73 of the mature telomerase ${ }^{13,14}$. If really both termination sites are equally used or if

74 one is preferred over the other under certain conditions is currently unclear.

75 Regardless of the transcription termination pathway used, the primary transcript is

76 always longer than the mature form. Clearly, some of the TLC1 molecules receive a

$77 \sim 80$ nucleotide long poly(A) tail after transcription, which is removed during the

78 maturation process and the exosome trims the pre-TLC1 RNA to 1158 nucleotides ${ }^{6}$.

79 In addition to these RNA-specific structural maturation events, TLC1 provides

80 a scaffold for several proteins ${ }^{15}$. In analogy to the snRNAs, the 3 '-end of TLC1 is

81 bound by a heptameric ring, composed of seven Sm-proteins, that encircles and

82 stabilizes $T L C 1^{11,16,17}$. Additionally, structurally important proteins as well as

83 regulatory and catalytic factors bind to the $T L C 1$ RNA. One of the stem loops that are

84 formed by $T L C 1$ is bound by the heterodimer Yku70-Yku80, which is important for a

85 persisting nuclear localization through attachment of the telomerase to chromosome

86 ends ${ }^{18,19}$. The central domain of $T L C 1$, which includes the template domain for

87 reverse transcription, is bound by the catalytic protein subunit Est2 and two accessory

88 factors Est 1 and Est $3{ }^{2,6}$. The Est-proteins are stabilized by the Pop1, Pop6 and Pop7 
89 proteins, which are also central components in the RNase MRP and the RNase $\mathrm{P}^{20,21 \text {, }}$

$90 \quad 22$.

91 Besides TLC1 processing and the protein loading onto this scaffold, this RNA

92 undergoes nucleo-cytoplasmic shuttling ${ }^{6,23}$. It is exported into the cytoplasm via

93 Mex67-Mtr2 and Xpo1/Crm1 ${ }^{23}$. On mRNAs and snRNAs the RNA-contact of

94 Mex67 is mediated by the guard proteins Np13, Gbp2 and Hrb1 24, 25, 26, 27 . Thus, a

95 similar mechanism is conceivable for $T L C 1$. For Xpo1/Crm1 a physical RNA contact

96 was shown via the cap binding complex (CBC) that interacts with the monomethyl

$97 \quad \operatorname{cap}^{24}$.

98 After loading of the Est-proteins and the Sm-ring in the cytoplasm, TLC1 is re-

99 imported into the nucleus via Mtr10 23, 28, 29. Prevention of shuttling, either by

100 mutations in the export factors or the import factor results in telomere shortening

101 defects and reduced TLC1 levels ${ }^{23,29,30}$.

For snRNAs the transfer to the cytoplasm was shown to be crucial for the generation of a functional spliceosome, because when not exported, the longer, unprocessed pre-snRNAs can be incorporated into the spliceosome and jeopardize splicing ${ }^{24}$. Thus, the immediate cytoplasmic drain of these noncoding RNAs is crucial for cell survival and might also be similarly important for the transcribed immature $T L C 1$.

Interestingly, maturation events such as trimming and TMG-capping were suggested to be nuclear events that occur prior to TLC1 shuttling and current models

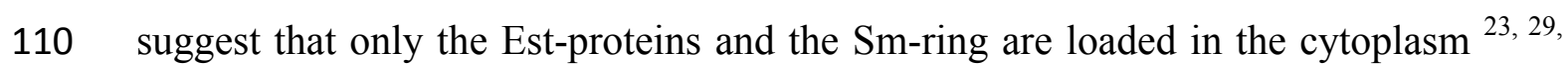

$111{ }^{30}$. Therefore, we investigated the maturation steps of $T L C 1$ in detail and uncovered a

112 stepwise process. We found that pre-TLC1 shuttles into the cytoplasm for the loading 113 of the Sm-ring, the Est- and the Pop-proteins. The subsequent re-import of the protein 
114 bound TLC1 precursor not only requires Mtr10, but also Cse1, a novel import

115 receptor for $T L C 1$. Defects in CSE1 result in Type I like survivors that show an

116 increased recombination phenotype, which is based on telomere elongation with

117 increased Y' elements. Both importer contact TLC1 via the Sm-ring. In this way the

118 nuclear entry of immature, or incomplete assembled TLC1 RNPs is prevented. Thus,

119 nuclear re-import resembles a quality control step in the life cycle of the telomerase

120 RNA. We further show that trimming of $T L C 1$ to the 1158 nucleotide short form is

121 carried out by the nuclear exosome after shuttling. In a final step, TMG-capping of

$122 T L C 1$ completes maturation. In summary we have uncovered that the maturation of

123 TLC1 occurs in a different order than anticipated and in a highly ordered manner,

124 including a cytoplasmic quality control step to ensure proper telomere function.

125 


\section{Results}

127 The Sm-ring is loaded to the precursor of $T L C 1$ in the cytoplasm. Sm-ring

128 binding to $T L C 1$ is a prerequisite for proper processing of this non-coding RNA,

129 while the contact of the TRAMP-complex and the nuclear exosome prior to the Sm-

130 ring attachment rather initiates full degradation of the transcript ${ }^{16,17}$. On snRNAs,

131 Sm-ring loading was recently identified to be a cytoplasmic event ${ }^{24}$. It was shown

132 that newly transcribed snRNAs are immediately exported from the nucleus to prevent

133 an incorporation of the precursor RNAs into the spliceosome, which jeopardizes

134 splicing ${ }^{24}$. TLC1 receives its Sm-ring also in the cytoplasm (Fig. 1 and ${ }^{29}$ ). To

135 analyze to which form the Sm-ring is loaded, the short 1158 nucleotide long mature

136 form or the longer premature form, we did the following experiments. First, we

137 extracted GFP-tagged Smb1 from cell lysates (Fig. 1A) and analyzed in RNA-co

138 immunoprecipitation (RIP) experiments the general binding of TLC1. Subsequent

139 qPCR experiments showed a clear binding of TLC1 to Smb1, which was normalized

140 to no tag as a negative control and related to 21S rRNA (Fig. 1B). Importantly, when

141 we repeated the experiment in the export mutant mex67-5 xpo 1-1 after shifting the

142 cells for $2 \mathrm{~h}$ to the non-permissive temperature, which prevents the export of newly

143 synthesized TLC1 molecules, we detected a significantly decreased binding between

144 the Sm-ring component Smb1 and TLC1 (Fig. 1C, D). These results suggest that the

145 inhibition of the nuclear export of TLC1 prevented the loading of the Sm-ring in the

146 cytoplasm.

147 This finding is further supported by a fluorescense in situ hybridization (FISH)

148 experiment targeting the TLC1 RNA with a Cy3-labeled probe. TLC1 is mostly

149 detectable in the nucleus of wild type cells (Fig. 1E) and ${ }^{23}$. However, in a double

150 mutant of smbl smd1, which has a defective Sm-ring ${ }^{31}$, TLC1 mislocalizes to the 
cytoplasm (Fig. 1E). These findings confirm that Sm-ring loading to TLC1 occurs in

152 the cytoplasm, which was also shown earlier via an inducible TLC1-RNA tagging

153 experiment and is very similar to the cytoplasmic Sm-ring loading onto the snRNAs

15424,29 . Therefore, we investigated the interaction between the Sm-ring and TLC1 in the

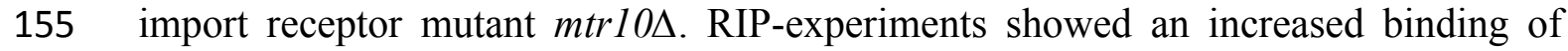

156 total TLC1 (Fig. 1G-I). To get information whether the mature or the immature form

157 of TLC1 accumulates, we also investigated the binding of the precursor of $T L C 1$ to

158 Smb1. A scheme of TLC1 shows that the primers amplifying the unprocessed variant

159 of $T L C 1$ will amplify any generated pre-TLC1, either the through NNS or CPF-CF

160 termination generated form (Fig. 1F).

161 Indeed, as shown in Fig. 1I, the binding of the immature TLC1 to Smb1

162 increased even more than the total $T L C 1$, suggesting that the immature form

163 accumulates in $m$ tr $10 \Delta$. These findings indicating that the Sm-ring is loaded in the

164 cytoplasm to the immature pre-TLC1 and the Sm-ring loaded TLC1 is accumulating

165 in the cytoplasm.

166 Futhermore, it was shown that the export of TLC1 requires Xpo1 in addition to

167 Mex67 ${ }^{23}$. For snRNA export it was shown that Xpo1 contacts the RNA via the cap

168 binding complex $(\mathrm{CBC})^{24}$. Since pre-TLC1 contains an $\mathrm{m}^{7} \mathrm{G}$ cap, it seems likely that

169 this 5' cap is also bound by CBC. However, this has not been shown so far.

170 Therefore, we carried out RIP experiments with Cbp20 and showed that the immature

171 form of TLC1 associates with this CBC-component (Fig. 1J-K). Together, these

172 findings suggest that pre-TLC1 export is supported by Xpo1.

173

174 Cse1 is a novel nuclear re-import factor for $\boldsymbol{T L C 1}$. Nuclear re-import of $T L C 1$

175 requires the nuclear import receptor Mtr10 ${ }^{28}$. Interestingly, snRNAs are re-imported 
176 via Mtr10 and Cse1, another member of the kayopherin transport factor family ${ }^{24}$.

177 After loading of the Sm-ring, Csel contacts the ring and supports nuclear re-import

178 of the snRNA, which resembles an important control step for maturation, because the

179 importer can only bind when the Sm-ring was successfully loaded ${ }^{24}$. As the Sm-ring

180 is also loaded onto TLC1 in the cytoplasm, it seems reasonable to assume that Cse1

181 would also participate in its nuclear re-import. Therefore, we localized TLC1 in the

182 cse 1-1 mutant that was shifted to $16^{\circ} \mathrm{C}$, as it is cold sensitive. We found that while

$183 T L C 1$ localized mainly to the nucleus in wild type cells, it was distributed throughout

184 the cytoplasm in the cse1-1 mutant (Fig. 2A), similar to mtr $10 \Delta$ and $y k u 70 \Delta$ strains

185 (Fig. 2A) and ${ }^{23,28}$. Since Mtr10 and Cse1 both contribute to the nuclear import of

186 TLC1 and snRNAs, we created a double mutant and assayed its growth. Although the

187 single mutants already showed growth defects in comparison to wild type, the double

188 mutant grew even less, indicating a genetic interaction between these import receptor

189 genes (Fig. 2B). Subsequent FISH experiments with the double mutant also showed a

190 cytoplasmic accumulation, similar to that observed in the single mutants (Fig. 2A).

191 However, the overall signal in the double mutant was slightly less intense, which

192 might reflect a decreased stability of $T L C 1$ in this strongly growth compromised 193 strain.

194 To verify binding of TLC1 to Cse1, we carried out RIP experiments, in which we

195 purified GFP-tagged versions of the import receptors Cse1 and Mtr10, of which the

196 latter served as a positive control (Fig. 2C, D). We found that the binding of TLC1,

197 most likely its immature form was significantly enriched, similar to the binding of the

198 snRNAs U1 and U5 (Fig. 2D) and ${ }^{24}$. A 1,5 to 2-fold increase of the binding,

199 although significant, might on first sight not seem to be very strong, but considering

200 that the binding of both import receptors depends on the small GTPase Ran the low 
value is understandable. For import-cargo complex formation Ran must be in its GDP

202 bound state. This is favored in the cytoplasm by the presence of the GTPase 203 activating protein RanGAP1 and its co-factor RanBP1 ${ }^{32,33,34}$. Cargo release from the

204 import receptors occurs in the nucleus where RanGTP is present and the nucleotide 205 exchange occurs with the nuclear exchange factor Prp20 (human RCC1) ${ }^{34}$. Upon cell 206 lysis for the RIP experiment, both compartments get mixed up and pre-formed 207 nuclear import complexes are attacked and disassembled through RanGTP. An 208 additional difficulty is the low copy number of $T L C 1$ with $\sim 10$ to $\sim 30$ copies per 209 haploid cell $^{6,35,36}$. However, despite these difficulties, we were able to detect binding 210 of TLC1 to both import factors, Mtr10 and Cse1 (Fig. 2C, D).

211 Analogous to mtr10D (Fig. 1H, I) we tested the binding of the Sm-ring in cse1-1

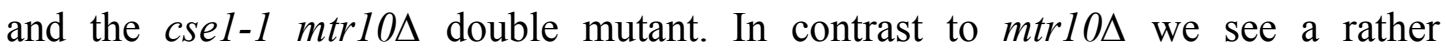
decreased binding of total $T L C 1$ and unprocessed $T L C 1$ in cse1-1, although the ratio 214 of immature TLC1 still exceeds the total TLC1 (Fig. 2 E-H). This observation 215 suggests that Cse1 prevents degradation of TLC1 when associated with the Sm-ring. 216 In the double mutant, in which both import receptors are missing, the Sm-ring 217 binding is even further reduced and the stability of $T L C 1$ is even worse, suggesting 218 that both import factors contribute to stabilization of the RNA waiting to be imported.

219 However, Cse1 seems to be important for the initial Sm-ring loading. In mtr10 the 220 Sm-ring bound RNA is more stable, suggesting that Csel is already sufficient to protect the immature $T L C 1$ in the RNP. Remarkably, we still detect higher amounts of the immature TLC1 bound to the Sm-ring (Fig. $2 \mathrm{H}$ ), suggesting that this form is trapped in the cytoplasm.

224 Similar results were also obtained when we analyzed the complete $T L C 1$ content 225 in cells. While the total TLC1 level decreased to approximately 50\% in mtr $10-1$ and 


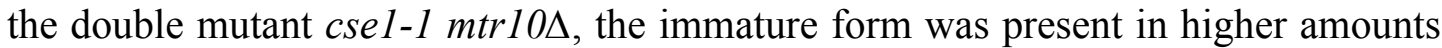

227 (Fig. 2I-K), suggesting a constant production of pre-TLC1, which does not finish maturation. Together, these findings identify Cse1 as a novel import receptor for TLC1 and show that optimal nuclear re-import of this a large RNP relies on more than one import receptor for its re-import and its stabilization.

\section{Mutation of CSE1 generates a Type I like survivor phenotype}

233 Prevention of nuclear TLC1 shuttling leads to shortened telomeres and thus mutations

234 in the export receptor Mex67 and Xpo1 as well as in the import receptor Mtr10 have

235 been reported to result in telomere shortening defects ${ }^{23,30}$. To investigate whether such defects would also be visible in the new import factor Cse1, we carried out southern blot analyses. Strikingly, we detected no shorter telomere ends in cse 1-1, but instead highly amplified subtelomeric Y' elements (Fig. 5A, B). Usually cells that lack the telomerase or components of it undergo senescence when telomeres become

240 critically short. The senescence phenotype is only temporary and most of these cells

241 lose their viability, but a small percentage of cells overcome this phenotype by

242 lengthening telomeres through homologous recombination, termed Type I and Type

243 II survivors ${ }^{37,38}$. Type I survivors depend on Rad51 and exhibit highly amplified

244 subtelomeric $\mathrm{Y}^{\prime}$ elements ${ }^{39}$, which are clearly visible in cse 1-1 cells (Fig, 5B and

245 5C). Thus, while the export receptor mutants and mtr10 $\Delta$ were not able to switch

246 their telotype to become Type I or Type II survivors and maintain stable but short

247 telomeres, mutation in CSE1 allowed homologous recombination, resulting in

248 amplified Y' elements to create Type I survivors, even without a prior senescence 249 phenotype. However, untypical for Type I survivors is that they have no short 
250 telomeres, as the case in csel-1 cells. Therefore, we designated them as Type I like

251

252

253

254

255

256

257

258

259

260

261

262

263

264

265

266

267

268

269

270

271

272

273

274

275 survivors.

In addition, we analyzed whether the telomeric phenotype in the cse 1-1 mutant can be reversed by introduction of a plasmid containing wildtype CSE1. Already after one restreak, which equals approximately 25 generations, and more clearly after 3 restreaks, the $\mathrm{Y}^{\prime}$ amplification band disapeared, indicating that the phenotype is based on the cse1 mutation (Fig. 5C). Furthermore, it can be seen that upon restreaking of the $t l c 1 \Delta$ strain on a plate, Type I survivors are generated ${ }^{40}$ and the typical $\mathrm{Y}^{\prime}$ band that appears is at the hight of that seen in cse1-1 (Fig. 5C).

Cse1 is also involved in the recycling of importin alpha, encoded by SRPI and cse 1-1 leads to an accumulation of Srp1 in the nucleus ${ }^{41}$. It was reported earlier that Srp1 might be involved in the nuclear localization of Est $1{ }^{42}$. Therefore, we examined whether TLC1 mislocalizes in an srp1-31 mutant. FISH experiments show no mislocalization of TLC1 in srp1-31 (Fig. 5D).

Pop protein loading onto $T L C 1$ occurs in the cytoplasm. After knowing the nuclear re-import requirements for $T L C 1$, we asked, where the proteins of the RNP are loaded onto TLC1 in the cell. We have suspected earlier that Est-protein binding occurs in the cytoplasm, as the Est-proteins accumulate in this compartment in a tlcl $\Delta$ mutant $^{23}$. Reassuringly, we also detect a cytoplasmic mislocalization for Est1GFP in the new TLC1 re-import factor mutant cse1-1 (Fig. 3A, B).

For the Pop proteins the place of loading onto $T L C 1$ is currently unknown. As the proteins are mostly localized to the nucleolus and the nucleoplasm ${ }^{43}$, it is possible that they are loaded after $T L C 1$ has completed its cytoplasmic phase and returned to the nucleus. The function of the Pop-proteins in TLC1 maturation is to stabilize Est1 and Est2 within the holoenzyme ${ }^{21,22}$. Therefore, it is also conceivable 
that they are loaded to $T L C 1$ in the cytoplasm, after the Est proteins were properly

277 attached. Importantly, Pop1 can only be stably associated with TLC1 when the

278 heterodimer Pop6 and Pop7 was attached to the RNA ${ }^{44}$. Thus, Pop1 binding is the

279 final step in the loading of the Pop-protein complex. We localized Pop1 in the TLC1

280 nuclear import- and export mutants and in tlc1s and found a clear cytoplasmic mislocalization of the protein, even though we detect its localization in wild type not as strict nuclear as published earlier with the identical constructs ${ }^{43}$ (Fig. 3C). Interestingly, also mutations in the Pop-proteins were shown to increase the

284 cytoplasmic presence of $T L C 1^{20}$, which supports a model in which loading of the 285 Pop-proteins might occur in the cytoplasm. Thus, in situations, in which TLC1 is not present in the cytoplasm, such as in $t l c 1 \Delta$ or in the export mutant mex67-5 xpo1-1, the Pop-proteins accumulate in the cytoplasm and most likely do not bind TLC1. However, in the import mutants, one would expect that the proteins were loaded onto $T L C 1$, but cannot be imported. To get additional support for a cytoplasmic loading and to find out whether Pop1 is loaded onto the long immature TLC1 we carried out RIP experiments, with strains that contained endogenously tagged POP1-GFP expressed from its own promoter to avoid overexpression. Clearly, we found a decreased binding of this RNA in the export mutant (Fig. 3D, E), while an import block resulted in an increased binding of the immature $T L C 1$ to Pop1 (Fig. 3F, G), suggesting that the loading of the Pop proteins is indeed a cytoplasmic event.

\section{Mtr10 contacts $T L C 1$ at the Sm-ring for nuclear re-import}

Cse1 can mediate the nuclear import of snRNAs and TLC1 only after the Sm-ring has properly assembled ${ }^{24}$ and (Fig. 1E). An interaction between the Sm-ring and Cse1 has been shown before ${ }^{24}$. Their interaction thus resembles a quality control step to 
301 allow only nuclear entrance of the Sm-ring-bound TLC1 RNP. It seems possible that

302 also Mtr10 may contact TLC1 only after proper protein loading has occurred. To

303 analyze potential complex formations, we carried out co-immunoprecipitations (co-

304 IPs) of Mtr10 with Pop1 and Est1. However, none of these proteins physically 305 interacted with Mtr10 (Fig. 4A and B).

306 It is currently unclear whether the Yku-heterodimer is loaded in the cytoplasm.

307 The Yku70-Yku80 heterodimer binds to a 48 nucleotide long stem loop of TLC1 and 308 is required for the nuclear localization of this RNA ${ }^{18,28,45}$ and (Fig. 2A). Therefore,

309 we investigated a potential binding between Mtr10 and Yku70 in co-IP experiments,

310 but we did not detect an interaction (Fig. 4C).

311 Finally, we investigated, whether Mtr10 might, like Cse1, also interacts with 312 the Sm-ring in co-IPs and indeed, a specific band of Mtr10 was detectable in the 313 eluates of the Smb1-IPs (Fig.4D). These findings indicate that both import receptors 314 interact with the Sm-ring to support nuclear import of the matured TLC1 RNP.

316 Processing of $T L C 1$ occurs in the nucleus after re-import of the protein bound

317 RNP. The longer pre-TLC1 is trimmed by the exosome up to the Sm-ring, resulting 318 in a $\sim 1150$ nucleotide long form ${ }^{6}$. Our studies in the re-import mutants suggest that 319 trimming occurs after shuttling, because of an increased Smb1-binding to the 320 immature precursor RNA of TLC1 (Fig. 1I, 2H). Moreover, mutants that accumulate 321 TLC1 in the cytoplasm accumulate immature TLC1 at decreasing total TLC1 levels 322 (Fig. 2I-K), suggesting that the TLC1 RNA is not trimmed before its journey through 323 the cytoplasm.

324 To further analyze this point, cytoplasmic fractionation experminets were carried out. 325 Compared to wild type cells, more unprocessed than total TLC1 accumulates in the 
cytoplasm of the import factor mutants (Fig, 6A and 6B). These findings suggest that

327 the immature form shuttles into the cytoplasm and trimming occurs afterwards by the nuclear exosome. Secondly, we assayed the TLC1-forms in the mex67-5 nuclear export mutant. We detected a decrease of total $T L C 1$, which is in agreement with earlier findings in which Mex67 was suggested to protect TLC1 from its degradation 29. However, in our experiments we still see a two-fold increase of the immature TLC1 in mex67-5 mutants, which suggests that immature TLC1 is not immediately degraded when Mex67 is missing (Fig. 6E). Possibly, other proteins such as the guard

334 proteins, one of which is Np13, that recruit Mex67 protect the immature form from 335 being degraded while waiting for export. To test whether Npl3 binds TLC1, we 336 precipitated the protein and found $T L C 1$, in particular the immature form to bind 337 Npl3 (Fig. 6 C, D). To address whether the trimming to the mature TLC1 occurs via 338 the nuclear exosome, we analyzed $T L C 1$ in rrp6 $\triangle$. Its deletion leads to an 339 approximately two-fold increase of the total $T L C 1$, which includes the mature form 340 and the immature form, and a 7-fold increase of the immature form of TLC1 (Fig. $3416 \mathrm{E}$ ), indicating that the immature form is trimmed in the nucleus. Remarkably, 342 although the RNA is less stable in mex67-5 mutants, the immature TLC1 still 343 increased five fold in the double mutant $\operatorname{rrp} 6 \Delta$ mex67-5, suggesting a) that its 344 trimming occurs in the nucleus and b) that the immature form is still protected 345 without Mex67. Furthermore it has to be noted, that in contrast to Vasianovich and 346 colleagues, we find no rescue of the decreased TLC1 in the double mutant rrp6 $\triangle$ 347 mex67-5 as detected by northern blot ${ }^{29}$. Since we applied in our experiments the 348 highly sensitive qPCR method, we were able to detect an increase of the immature 349 TLC1 when its export is blocked in mex67-5, despite the overall decrease of the total $350 T L C 1$ in both mutants (Fig. 6E). 
16. Our data furthermore suggest that the immature $T L C 1$ is protected from degradation by Mex67 binding and its immediate export activity into the cytoplasm.

356 But they also suggest that additional proteins, like Npl3, protect the immature TLC1

357 from degradation, possibly the guard proteins that recruit Mex67 after quality control, as the immature form increases in the nucleus of mex67-5 mutants (Fig. 6D and 6E).

Our data further indicate that rather the mature form of $T L C 1$ is degraded when Mex67 is mutated, which might reflect its regulsar turnover rate when no new telomerase is made.

Another modification of $T L C 1$ is the TMG-capping at its 5' end in the nucleolus by Tgs1 ${ }^{10,46}$. To investigate, whether this trimethylation occurs before or after shuttling we carried out RIPs experiments with a TMG-cap specific antibody. Subsequently, we carried out qPCRs to detect TLC1. As compared to wild type, we found an approximately $30 \%$ decrease in the level of the TMG-capped TLC1 in a TGS1 deletion strain, which resembles the zero-line for the unspecific binding of this antibody, because Tgs1 is the only trimethyltransferase in yeast. Clearly, also in the single import mutants $m$ tr $10 \Delta$ and $c s e 1-1$ as well as in the double mutant we found a reduction, which was around $30 \%$ (Fig. 6F). These findings indicate that TMGcapping occurs after shuttling.

374 of the longer precursor TLC1 into the cytoplasm by Mex67, probably assisted by $375 \mathrm{Npl3}$ and Xpo1 that binds to the CBC. In the cytoplasm not only the Sm-ring is 
376 loaded, but also the Est- and the Pop-proteins attach to the immature TLC1. Its

377 successful assembly allows Mtr10 and Cse1 to bind and re-import pre-TLC1 into the

378 nucleus. Subsequently, trimming of the immature form into the mature $\sim 1150$

379 nucleotide long form is mediated by the nuclear exosome and TMG capping finally

380 occurs in the nucleolus by Tgs1.

381 In our compiled investigation we have ordered the maturation process of TLC1

382 and show the order of events from nuclear export of the premature transcript to the

383 binding of the Est- and Pop-proteins and the Sm-ring in the cytoplasm to its trimming

384 and TMG-capping after re-import into the nucleus. We show that the Sm-ring binding

385 resembles a quality control step that enables subsequent movement of the RNP into

386 the nucleus. Thus, the step-wise maturation of TLC1 is controlled by its

387 compartmental shuttling. 
388

389

390

391

392

393

394

395

396

397

398

399

400

401

402

403

404

405

406

407

408

409

410

411

412

\section{Discussion}

Functional telomerases are important to prevent the repetitive shortening of the DNA ends after each round of replication for recurrent cell divisions. Due to the fact that these holoenzymes undergo a stepwise assembly, a danger is that incompletely assembled telomerases interfere with the process of telomere elongation. In the worst case, these immature telomerases could, due to their restricted or absent functionality, prevent telomere maintenance. To avoid such a scenario, a mechanism has developed, in which the RNA scaffold, TLC1 in yeast, is exported into the cytoplasm via the export receptors Mex67-Mtr2 and Xpo1/Crm1 ${ }^{23,28}$. While Xpo1/Crm1 contacts the $\mathrm{CBC}$, which is bound to the monomethyl cap of the RNA-polymerase II transcribed RNA, Mex67-Mtr2 was speculated to contact the RNA via the adapter proteins Np13, Gbp2 and Hrb1, because such contact is observed for mRNA and snRNA export ${ }^{24,25,26,27}$.

Binding of the Est proteins to $T L C 1$ and association of the Sm-ring were suggested to be cytoplasmic events, while TMG-capping and trimming of TLC1 were suggested to occur in the nucleus prior to shuttling ${ }^{23,28,29}$. Up to date, the place of the Pop-protein loading onto TLC1 was unknown, but suspected to occur in the cytoplasm, because mutants of $P O P 1$ and $P O P 6$ accumulated $T L C 1$ in the cytoplasm 20. We collected additional evidence for a cytoplasmic Pop-protein loading and analyzed the localization of Pop1 in the import factor mutants. We found an accumulation of Pop1 in the mutants (Fig. 3C), supporting the idea of their cytoplasmic loading and supporting the newly discovered role of Cse1 in TLC1 nuclear import. Finally, we could confirm this result through RIP experiments in which we detected a decreased binding to Pop1 in mex67-5 and an increased binding in the import mutant cse1-1 (Fig. 3E, G). As the function of the Pop-proteins is to 
413 stabilize the Est proteins on the RNA and to support the RNP structure ${ }^{21,22}$ their

414 cytoplasmic loading seems to be a final step before re-import.

415 Another important event is the loading of the Sm-ring that limits the trimming 416 of the TLC1 precursor, which was recently shown to occur in the cytoplasm, similar 417 to the Sm-ring loading onto snRNAs ${ }^{24,29}$. However, in the interesting study of

418 Vasianovich and colleagues a modified TLC1 that contained several MS2 stem loops 419 was used, which could have an influence on its localization. In our study we used 420 probes and primers that 1) detect the unmodified natural TLC1 and 2) selectively 421 detect the immature $T L C 1$-precursor. With this method we confirmed the data of 422 Vasianoivich and colleagues and show that the Sm-ring loading is a cytoplasmic 423 event. But in addition, we have shown that the Sm-ring and the Pop-proteins associate with the immature precursor of TLC1 in the cytoplasm (Fig. 1I, 2H and 3G) and that trimming occurs after Sm-ring loading and after re-import into the nucleus (Fig. 1I, 1K, 2H-K, 3E, 3G, 6E).

It was shown that the karyopherin Cse1 contacts the Sm-ring and particularly

428 Smb1 for nuclear re-import of the snRNAs ${ }^{24}$. Interestingly, we also detected a 429 binding between the Sm-ring and the other import factor, Mtr10 (Fig. 4D). This 430 finding is important for three reasons. First, besides Mtr10, Cse1 is another import 431 factor that facilitates the transit of this huge RNP through the NPC. The more 432 transport factors are involved in transporting large particles, the better the transit is 433 working. This is supported by the additive effect for the mislocalization of TLC1 seen 434 in the combined import factor mutants (Fig. 6A,B). Secondly, a potential failure of 435 one of the import receptors does not fully prevent TLC1 re-import. Third, nuclear re436 import supported by Mtr10 and Cse1 can only occur on TLC1 molecules that have 437 received the Sm-ring, which resembles an elegant way of cellular quality control for 
this important maturation step of the telomerase. For this, Cse1 might be more important because we detect a decreased binding of TLC1 to Smb1 in cse1-1 cells,

440 even though we see no drastic change in the overall amount of TLC1 (Fig. 2F-K).

441 Together, these findings argue for a control step in the RNP formation, which

442 prevents that faulty RNPs can enter the nucleus and jeopardize telomere function.

443 However, we cannot exclude that another protein is involved in its stabilization,

444 which is dependent on Cse1 transport. In every sense, Sm-ring loading is an essential

445 step in maturation and allows nuclear re-import of pre-TLC1.

446 Interfering with the shuttling of $T L C 1$ either by mutation of the export factors

447 Mex67 and Xpo1 or the import receptor Mtr10 was shown to result in telomere 448 shortening defects ${ }^{23,30}$. Interestingly, we did not detect any telomere shortening 449 defects for the novel TLC1 re-import factor Cse1. Instead, mutation of CSE1 resulted 450 in a Type I like survivor phenotype, which is characterized of being capable to 451 amplify subtelomeric Y' elements (Fig. 5A, B). Type I survivors can escape cell 452 death by lengthening their telomeres through homologous recombination ${ }^{37}$. cse $1-1$ 453 seems to belong to the Type I survivors, because it shows the typical highly amplified 454 subtelomeric $\mathrm{Y}^{\prime}$ elements generated via homologous recombination, even though 455 cse1-1 cells show no shortening in the termial fragment. Thus, while the export 456 receptor mutants and mtr $10 \Delta$ did not allow telomere elongation via recombination, a

457 mutation in CSE1 does. As the Y-element amplification is based on homologous 458 recombination by the recombinase Rad51, one can speculate that either Rad51 itself, 459 or factors of the Rad51 homologous recombination pathway might not be imported in $460 m \operatorname{tr} 10 \Delta$, so that mtr $10 \Delta$ mutants cannot use homologous recombination for telomere 461 maintanace but rather show a shortening of the telomeres. Other survivors are 462 mutants of telomere capping components, since very short or uncapped telomeres are 
463 prone to recombination despite a functional telomerase ${ }^{47,48,49}$. Therefore, we cannot

464 exclude that Cse1 might import one of these proteins. Nevertheless, the

465 mislocalization of TLC1 in the cytoplasm of the cse1 mutants suggests rather a direct 466 effect.

467 Moreover we have excluded an involvement of Srp1 in the localization of 468 TLC1. In the srp1-31 mutant, no mislocalization of TLC1 was observed (Fig 5D). 469 Srp1 was suggested to mediate the nuclear localization of Est1 and since Srp1 470 mislocalizes in the cse $1-1$ mutant an influence was conceivable ${ }^{41,42}$. However, the 471 type I like survivor phenotype does not appear to be dependent on Srp1, as mutation 472 of SRP1 does not lead to a mislocalization of $T L C 1$.

473 At steady state about 80 to $90 \%$ of $T L C 1$ are present in the mature shorter form 474 which is present in the functional telomerase and only a small fraction is present as 475 the polyadenylated longer form ${ }^{12,8}$. Older model discuss the CPF-CF terminated $476 \operatorname{poly}(\mathrm{A})^{+}$form as a precursor of the mature form ${ }^{12}$, but more recent studies suggest 477 that the NNS terminated form might be the prominent one ${ }^{14}$. Therefore, it is 478 currently unclear how much of the TLC1 originates from NNS or CPF-CF 479 termination. However, since both versions a) need to adopt the Sm-ring for general 480 protection, which was shown to be a cytoplasmic process ${ }^{24}$ and b) total $T L C 1$ 481 significantly decreases if shuttling is prevented (Fig. 2F, I) and c) leads to a defect in 482 the telomeres (Fig. 5) and ${ }^{23}$, shuttling of any immature form seems highly relevant.

483 It was unclear when trimming occurs. Earlier studies indicated that mutations in 484 the nuclear component of the exosome resulted in a strong increase of TLC1 ${ }^{16}$. 485 However, the experimental set up neither allowed to distinguish between the mature 486 form or the immature poly $(\mathrm{A})^{+}$precursor of $T L C 1$, nor whether the exosomal 487 trimming occurred before or after shuttling. To determine the time and place of the 
TLC1 trimming, we first showed that the immature form accumulates in nuclear reimport mutants and in mutants that are defective in the Sm-ring assembly (Fig. 1 and 2I-K). Additionally we have shown by nucleo-cytoplasmic fractionation experiments

491 that the immature form accumulates in cytoplasm in the import factor mutants (Fig 492 6B), which indicates that trimming occurs after re-import. Furthermore, mutation of 493 RRP6 resulted in a strong increase of the immature TLC1 precursor (Fig. 6E), suggesting that the nuclear exosome is responsible for trimming after shuttling. This finding also suggests that the immature form is still protected without Mex67. One possibility is that the Mex67-interacting and RNA-binding proteins Npl3, Gbp2 and Hrp1 might guard $T L C 1$. And indeed, we have shown that $T L C 1$ and especially the immature $T L C 1$ is bound by Np13 (Fig. 6D). Co-transcriptionally loading of Npl3 prior to binding of Mex67 $7^{50,51}$ provides coverage and thus protection of the RNP.

501 because unprotected RNA is an ideal substrate for the exosome ${ }^{17}$. Interestingly, 502 preventing nuclear export by mutation of MEX67 leads to a decrease of TLC1 (Fig. $5036 \mathrm{E}$ and ${ }^{29}$ ). During the short period of time in which the immature TLC1 RNA is usually present in the nucleus before Mex67 and Xpo1 export it into the cytoplasm,

505 the nuclear exosome is not able to attack the RNA sustainably. Thus, Mex67 cannot

506 be the only protecting RNA-binding protein, because even in mutants of this export 507 receptor we detect a $\sim 5$-fold increase of the immature TLC1 in rrp6 6 mex67-5 as 508 compared to wild type. Possibly this is achieved by guard proteins such as Npl3 that 509 recruit Mex67 27,51 .

510 Our finding that the Sm-ring loading occurs in the cytoplasm prior to TMG-

511 capping is in agreement with other studies that have shown that the Sm-ring is crucial 512 for trimethylation of the cap ${ }^{52}$. Furthermore, we have shown earlier that snRNAs are 
513 retained in the nucleolus when Smb1 is depleted that showed that an intact Sm-ring is

514 required for efficient trimethylation and subsequent nucleolar release into the

515 nucleoplasm. It is well conceivable that the formed Sm-ring assists TMG-capping, as

516 it interacts with Tgs1 both, in vivo and in vitro ${ }^{10,24}$.

517 Importantly, snRNA nucleo-cytoplasmic shuttling was suggested to be

518 terminated by trimethylation of the $5^{\prime}$ cap $^{24}$. The export receptor Xpo1 interacts with

519 the 5' cap binding complex CBC, in particular with Cbp80 ${ }^{24}$. This might be similar

520 for $T L C 1$, because pre- $T L C 1$ contains an $\mathrm{m} 7 \mathrm{G}$ cap, which is bound to $\mathrm{CBC}($ Fig. $1 \mathrm{~K})$

521 and TLC1 interacts with Xpo1 ${ }^{23}$. After receiving the TMG cap, CBC might not be

522 bound and Xpo1 then unable to interact. Since the other export receptor, Mex67, is

523 already displaced at the NPC when entering the cytoplasm ${ }^{53,54}$, Xpol is the only

524 transport factor left for a repeated snRNA export and TMG capping could close this

525 option. Therefore, it seems logic that TMG capping on TLC1 also occurs after

526 shuttling and maturation and we could indeed show that preventing nuclear re-import

527 of $T L C 1$ results in the accumulation of $\mathrm{m}^{7} \mathrm{G}$, but not TMG capped RNAs (Fig. 6F).

528 Together, our analysis uncovered the steps in which telomerase maturation

529 takes place (Fig. 7) and identified that proper cytoplasmic assembly of the telomerase

530 is prerequisite for nuclear re-import and thus represents a quality control check point

531 in the life cycle of this holoenzyme. Any way of interfering with the compartmental

532 maturation process inevitably leads to defects in telomere biology (Fig. 5) and 18, 20, 23,

$53328,30,55,56$, reflecting the importance of this step-wise process. 


\section{Experimental procedures}

535 Yeast strains, plasmids and oligonucleotides. All yeast strains used in this study are

536 listed in the Supplemental Table 1, oligonucleotides in Supplemental Table 2 and 537 plasmids in Supplemental Table 3. Plasmids and yeast strains were generated by 538 conventional methods.

540 Fluorescent in situ hybridization experiments (FISH). The experiments were

541 essentially carried out as described ${ }^{24}$. RNA probes were with Cy3-labeled 542 oligonucleotides (Sigma), which are listed in Supplementary Table 2. Cells were 543 grown to mid $\log$ phase $\left(1 \times 10^{7}\right.$ cells $\left./ \mathrm{ml}\right)$ prior to temperature shift to $37^{\circ} \mathrm{C} 1 \mathrm{~h}$ or $2 \mathrm{~h}$ 544 or to $16{ }^{\circ} \mathrm{C}$ for $1 \mathrm{~h} 15 \mathrm{~min}$ (Fig. 2A, 5D). For Sm-ring dependent localization studies, 545 cells were grown to $\log$ phase in YP medium containing $2 \%$ galactose. Afterwards $5464 \%$ glucose was added and cells were incubated at $25^{\circ} \mathrm{C}$ for $2 \mathrm{~h}$ (Fig. 1E). Samples 547 were fixed by adding formaldehyde to a final concentration of $4 \%$ for $45 \mathrm{~min}$ at 548 room temperature. Cells were spheroplasted by adding zymoylase, subsequently 549 permeabilized in $0.1 \mathrm{M}$ potassium phosphate buffer $\mathrm{pH} 6.5,1.2 \mathrm{M}$ sorbitol, $0.5 \%$ 550 Triton ${ }^{\circledR}$ X-100, pre-hybridized with Hybmix (50\% deionized formamide, $5 \times$ SSC,

551 1x Denhardts, $500 \mu \mathrm{g} / \mathrm{ml}$ tRNA, $500 \mu \mathrm{g} / \mathrm{ml}$ salmon sperm DNA, $50 \mu \mathrm{g} / \mathrm{ml}$ heparin, $5522.5 \mathrm{mM}$ EDTA pH 8.0, 0.1\% Tween ${ }^{\circledR} 20$ ) for $1 \mathrm{~h}$ on a polylysine coated slide at $55337^{\circ} \mathrm{C}$ and hybridized in Hybmix with the specific probe over night at $37^{\circ} \mathrm{C}$. After 554 hybridization, cells were washed with 2x SSC and 1x SSC at room temperature, each 555 for $1 \mathrm{~h}$ and $0.5 \mathrm{x} \mathrm{SSC}$ at $37^{\circ} \mathrm{C}$ and room temperature, each for $30 \mathrm{~min}$. DNA was 556 stained with Hoechst 33342 (Sigma). Microscopy studies were performed with a

557 Leica AF6000 microscope and pictures were obtained by using the LEICA 558 DFC360FX camera and the LAS AF 2.7.3.9 software (Leica). For deconvolution 
559 (Fig. 1E, 2A and B) z-stacks (10 stacks; 0,2 $\mu \mathrm{m}$ ) were recorded and the maximal

560 projection was deconvoluted with 3 iterations by the LAS AF 2.7.3.9 software

561 (Leica).

562

563 RNA co-immunoprecipitation experiments (RIP). All yeast strains were grown to

564 mid $\log$ phase $\left(2 \times 10^{7}\right.$ cells/ml). For RIP experiments seen in Fig. 1 A, B, J, K; 2 C, D

565 and $6 \mathrm{C}$ and D cells were cultured at $25^{\circ} \mathrm{C}$, in $1 \mathrm{C}, \mathrm{D}, \mathrm{H}, \mathrm{I} ; 2 \mathrm{E}-\mathrm{H} ; 3 \mathrm{D}-\mathrm{G}$ and $6 \mathrm{~F}$ cells

566 were shifted to a non-permissive temperature for $1 \mathrm{~h} 37^{\circ} \mathrm{C}$ or $16{ }^{\circ} \mathrm{C}$ respectively.

567 Afterwards cells were harvested and lysed in RIP buffer $(25 \mathrm{mM}$ Tris $\mathrm{HCl} \mathrm{pH} 7.5$,

$568100 \mathrm{mM} \mathrm{KCl}, 0.2 \%(\mathrm{v} / \mathrm{v})$ Triton $\mathrm{X}-100$ (1\% Triton X-100 for 2E), $0.2 \mathrm{mM}$ PMSF,

$5695 \mathrm{mM}$ DTT, $10 \mathrm{U}$ RiboLock RNase Inhibitor (Thermo Scientific) and protease

570 inhibitor (Roche) using the FastPrep ${ }^{\circledR}-24$ machine (MP Biomedicals) three times for

$57130 \mathrm{sec}$ at $5.5 \mathrm{~m} / \mathrm{s}$. After centrifugation the supernatant was incubated for $1 \mathrm{~h}$ at $4{ }^{\circ} \mathrm{C}$

572 with GFP-Selector beads (NanoTag) (Fig. 1 B,D, H, I, K; 2 D, F-H; 3 E, G and 6D).

573 For TMG-cap-IPs total RNA was extracted from yeast lysates using trizol-chloroform

574 (Ambion ${ }^{\circledR}$ RNA by Life technologies ${ }^{\mathrm{TM}}$ ). $50 \mu \mathrm{g}$ of the total RNA was incubated for

$5751 \mathrm{~h}$ at $4{ }^{\circ} \mathrm{C}$ with $10 \mu \mathrm{l}$ of the anti-2,2,7-trimethylguanosine-antibody (Calbiochem

576 Milipore) coupled to sepharose beads (Fig. 6F). Detection occurred via an anti-

577 digoxygenin antibody coupled to alkaline phosphatase $(1: 10,000)$ (Roche).

578 The beads were washed five times with RIP buffer and for GFP-RIP split in two 579 portions after the last washing step. Proteins were detected by western blot (1A, C, G

580 and J; 2C, E; 3 D, F and 6C). Eluates were purified via trizol-chloroform (Ambion ${ }^{\circledR}$

581 RNA by Life technologies ${ }^{\mathrm{TM}}$ ) extraction. The purified RNA was measured via

582 Nanodrop and a defined amount of RNA was reverse transcribed with FastGene

583 Scriptase II (Nippon Genetics) for subsequent qPCR analyses. To normalize the total 
584 RNA amount, we used the mitochondrial $21 \mathrm{~S}$ rRNA. For comparisons, we always

585 related the immature to the total $T L C 1$. All eluates were related in each strain to the

586 lysates to account for strain-specific variations in the total amount.

587

588 Total RNA Isolation. Total RNA Isolation was carried out with the NucleoSpin

589 RNA Kit from Macherey-Nagel. All steps were performed according to the 590 manufactures description, except step 7. The DNA digestion on the column was

591 executed for 1 hour. An additional DNA digestion step was carried out after elution

592 of the RNA. For the additional DNA digest the eluted RNA was mixed with a 10th

593 volume of the Reaction Buffer for rDNAse and $1 \mu 1$ rDNAse, according to the 594 manufactures description. The digest was incubated for 1 hour at $37^{\circ} \mathrm{C}$, before it was 595 terminated through sodium acetate ethanol precipitation. For this 0.1 volume $3 \mathrm{M}$ 596 sodium acetate, $\mathrm{pH} 5.2,2.5$ volumes of $99 \%$ pure ethanol and $1 \mu 1$ glycoblue were 597 mixed with the RNA and incubated over night at $-20^{\circ} \mathrm{C}$. For normalization, the $21 \mathrm{~S}$ 598 rRNA amount was determined. In Fig. $2 \mathrm{H}$ and $\mathrm{K}$ and $6 \mathrm{~B}$, the enrichment of the 599 unprocessed form was shown in comparison to total $T L C 1$ amount. For this purpose,

600 the total amount present in each strain was used as normalization to account for strain 601 internal variations.

602

603 Nucleo-cytoplasmic fractionation experiment

604 For the detection of TLC1 in the cytoplasm (Fig. 6B) cells were grown to mid log605 phase $\left(2 \times 10^{7}\right.$ cells $\left./ \mathrm{ml}\right)$. The cells were harvestet by centrifugation for $5 \mathrm{~min}$ at 4000 $606 \mathrm{rpm}$. Cells were washed once with $1 \mathrm{ml}$ YPD/ $1 \mathrm{M}$ Sorbitol/ $2 \mathrm{mM}$ DTT and 607 resuspended in YPD/ $1 \mathrm{M}$ Sorbitol/ $1 \mathrm{mM}$ DTT. Cells were spheroblasted using $1 \mathrm{mg}$ 608 zymolyase $(100 \mathrm{mg} / \mathrm{ml})$ and after that diluted in $50 \mathrm{~mL}$ YPD/ 1 M Sorbitol for $30 \mathrm{~min}$ 
610 (cse1-1 and cse1-1 mtr 104). Cells were placed on ice, centrifuged at $2000 \mathrm{rpm}$ for 10

$611 \mathrm{~min}$ and the pelleted cells were resuspended in $500 \mu \mathrm{l}$ Ficoll buffer (18\% Ficoll 400,

$61210 \mathrm{mM}$ HEPES $\mathrm{pH}$ 6.0) and $1 \mu 1$ Ribolock. Cells were lysed by addition of $1 \mathrm{ml}$ 613 buffer A (50 mM NaCl, $1 \mathrm{mM} \mathrm{MgCl2,10} \mathrm{mM} \mathrm{HEPES} \mathrm{pH} \mathrm{6.0).} \mathrm{The} \mathrm{suspension} \mathrm{was}$ 614 mixed and centrifuged at $4000 \mathrm{rpm}$ for $15 \mathrm{~min}$. The supernatant was used for 615 cytoplasmic analyses. RNA was isolated using the Nucleo-Spin RNA Kit (Macherey 616 and Nagel). The purified RNA was reverse transcribed with FastGene Scriptase II 617 (Nippon Genetics) for subsequent qPCR analyses. All values were normalized to the 618 amount of the mRNA present for RPL8A. To verify no nuclear contamination in the 619 cytoplasmic fraction, aliquots of the samples were analyzed in western blots for the 620 presence of the cytoplasmic Zwf1 protein and the absence of the nuclear Nop1 621 protein (Fig. 6A).

622

623 GFP-microscopy. Cells were grown, treated and harvested as described in the FISH 624 experiments. Cells were fixed with $3 \%$ formaldehyde for $2 \mathrm{~min}$ at room temperature, 625 subsequently washed with $0.1 \mathrm{M}$ phosphate buffer $\mathrm{pH} 6.5$ and with P-solution $(0.1 \mathrm{M}$ 626 phosphate buffer $\mathrm{pH}$ 6.5, 1.2M Sorbitol), before an aliquot was added to a polylysine627 coated slide for $30 \mathrm{~min}$ at $4{ }^{\circ} \mathrm{C}$. Permeabilization of the cells, DNA staining and microscopy was performed as described in the FISH experiment.

629

630 Co-immunoprecipitation (IP) experiments. All yeast strains were grown to log 631 phase $\left(2-3 \times 10^{7}\right.$ cells $\left./ \mathrm{ml}\right)$. Afterwards, the cells were harvested and lysed in IP buffer 632 (1 x PBS, $3 \mathrm{mM} \mathrm{KCl}, 2.5 \mathrm{mM} \mathrm{MgCl}, 0,5 \%$ Triton $\mathrm{X}-100$ and protease inhibitors 633 from Roche). $35 \mu 1$ of this lysate was loaded onto an SDS-gel (lysate lanes). The 
634 supernatant was incubated for $1 \mathrm{~h}$ at $4{ }^{\circ} \mathrm{C}$ with GFP-Selector beads (NanoTag) (Fig.

6354 4, B and D) or with Myc-trap beads (Chromotek) (Fig. 4C). The beads were washed

636 five times with IP buffer, and finally resuspended in $35 \mu 1$ SDS-sample buffer. The

637 entire eluate sample was loaded onto the SDS-gels.

638 Subsequently, the proteins were detected by Western blot analyses with the indicated 639 antibodies (GFP (Chromotek) 1:4,000; c-myc (9E10) (Santa Cruz) 1:1,000; Hem15 640 and Grx4 each 1:5,000 and Aco1 1:2,000 (U. Mühlenhoff); Nop1 (Santa Cruz) 641 1:4,000; Hdf1(Yku70) (Santa Cruz) 1:4,000). Signals were detected with the Fusion 642 SL system (PeqLab) and FusionFX7 Edge (Fusion FX Vilber). To be able to detect 643 several proteins in one experiment, the western blots were cut horizontally according 644 to the size of the desired proteins to be able to detect each stripe with individual 645 antibodies

646

647 Drop dilution analysis. Cells were grown to $\log$ phase $\left(2-3 \times 10^{7}\right.$ cells $\left./ \mathrm{ml}\right)$ and diluted 648 to $1 \times 10^{7}$ cells $/ \mathrm{ml}$. 10 -fold serial dilutions to $1 \times 10^{3}$ cells $/ \mathrm{ml}$ were prepared and $10 \mu 1$ of 649 each dilution was spotted onto full medium (YPD) agar plates that were subsequently 650 incubated for 3 days at the indicated temperatures (Fig. 2 B). Pictures were taken 651 after 2 and 3 days with the Intelli Scan 1600 (Quanto technology) and the SilverFast 652 Ai program.

653

\section{Southern blot analysis}

655 Yeast strains were either passaged in liquid culture (Fig. 5B) or on solid agar plates 656 (Fig. 5C). For passaging in liquid culture, cells were inoculated with a starting 657 concentration of $1 \times 10^{5}$ cells $/ \mathrm{ml}$. The strains were grown for 3 days per passage at 20 
$658{ }^{\circ} \mathrm{C}$ until they reached $1 \times 10^{8}$ cells $/ \mathrm{ml}$ and were afterwards diluted again to $1 \times 10^{5}$.

659 Overall 8 passages, corresponding to 80 generations, were carried out.

660 Cell passages on solid agar plates were used for generating Type I survivors in tlc1 $\Delta$

661 cells. The strains were freshly restreaked form the database and single colonies were

662 restreaked after $2-3$ days at $25^{\circ} \mathrm{C}$. One restreak comprises about 25 generations.

663 Overall 5 restreaks were generated coresponding to about 125 generations.

664 Genomic DNA was isolated with the MasterPure Yeast DNA Purification Kit

665 (Lucigen). This gDNA was digested with XhoI (Nippon Genetics) according to the 666 manufactures description. $20 \mu \mathrm{g}$ gDNA were loaded per lane and electrophoretically 667 separated on a $1 \% \mathrm{TBE}$ gel at $4^{\circ} \mathrm{C}$ for 3 hours. The gel was depurinated $(250 \mathrm{mM}$ $668 \mathrm{HCl})$ for 15 minutes, denatured $(1.5 \mathrm{M} \mathrm{NaCl}, 0.5 \mathrm{M} \mathrm{NaOH})$ for 30 minutes, 669 neutralized (1.5 M NaCl, 0.5 M Tris-HCL, pH 7.5) for 30 minutes and equilibrated in $67020 \mathrm{x}$ SSC (0.3 M Tri-sodium citrate, $3 \mathrm{M} \mathrm{NaCl}, \mathrm{pH} 7.0)$ for 15 minutes. A capillary 671 blot was used for the transfer onto a HybondN ${ }^{+}$(GE Healthcare) membrane. After 672 transfer, the membrane was crosslinked for 7 min by UV light $(254 \mathrm{~nm}, 120000$ $673 \mu \mathrm{J} / \mathrm{cm}^{2}$ ) and then heated to $80{ }^{\circ} \mathrm{C}$ for $2 \mathrm{~h}$. Subsequently, pre-hybridization was carried 674 out for $1 \mathrm{~h}$ at $68{ }^{\circ} \mathrm{C}$ in pre-hybridization buffer $(0.5 \mathrm{M}$ sodium phosphate buffer $\mathrm{pH}$ 6757,$5 ; 7 \%(\mathrm{w} / \mathrm{v})$ SDS; $1 \mathrm{mM}$ EDTA). For hybridization, a digoxygenin-labeled probe, 676 detecting the TG repeats of the telomeres, was added to the pre-hybridization solution 677 and incubated over night at $37^{\circ} \mathrm{C}$ with rotation. After washing, the southern blot was 678 detected by using an anti-digoxygenin antibody coupled to alkaline phosphatase 679 (Roche) and the labeling and detection starter kit (Roche). 680 
682 Quantification. All experiments shown in this work were performed in biologically

683 independent repetitions as indicated in the figure legends. Error bars represent the

684 standard deviation. $\mathrm{P}$ values were calculated using a two-tailed, two-sample equal

685 variance t-test. $\mathrm{P}$ values are indicated as follows: ***p $<0.001$, **p $<0.01, * \mathrm{p}<$

6860.05.

687

688 Acknowledgements

689 We are grateful to R. Bordonné, E. Hurt, U. Mühlenhoff, R. Lill, V. Lundblad, E.

690 O'Shea, P.A. Silver, A. Tartakoff and K. Weis for providing plasmids, strains or 691 antibodies. This work was supported from the Deutsche Forschungsgemeinschaft 692 (DFG) and the SFB860 awarded to H.K.

693

694

695 Author contributions

696 Experiments were designed and data interpreted by A.G.H., D.B., J-P.L. and H.K.; all 697 experiments were performed by A.G.H. except 1 E, which was done by D.B; 2A by 698 A.G.H. and D.B.; 2B, 3A,B,C by A.G.H and J.-P.L.. The manuscript was written by 699 H.K.; all authors discussed the results and commented on the manuscript. 
700

701

702

703

704

705

706

707

708

709

710

711

712

713

714

715

716

717

718

719

720

721

722

723

724

725

726

727

728

729

730

731

732

733

734

735

736

737

738

739

740

741

742

743

744

745

746

\section{References}

1. Armstrong CA, Tomita K. Fundamental mechanisms of telomerase action in yeasts and mammals: understanding telomeres and telomerase in cancer cells. Open Biol 7, (2017).

2. Vasianovich $\mathrm{Y}$, Wellinger RJ. Life and Death of Yeast Telomerase RNA. Journal of molecular biology, (2017).

3. Blackburn EH, Epel ES, Lin J. Human telomere biology: A contributory and interactive factor in aging, disease risks, and protection. Science (New York, NY 350, 1193-1198 (2015).

4. O'Sullivan RJ, Karlseder J. Telomeres: protecting chromosomes against genome instability. Nature reviews 11, 171-181 (2010).

5. Rousseau P, Autexier $\mathrm{C}$. Telomere biology: Rationale for diagnostics and therapeutics in cancer. RNA Biol 12, 1078-1082 (2015).

6. Gallardo F, Chartrand P. Telomerase biogenesis: The long road before getting to the end. RNA Biol 5, 212-215 (2008).

7. Zappulla DC. Yeast Telomerase RNA Flexibly Scaffolds Protein Subunits: Results and Repercussions. Molecules 25, (2020).

8. Bosoy D, Peng Y, Mian IS, Lue NF. Conserved N-terminal motifs of telomerase reverse transcriptase required for ribonucleoprotein assembly in vivo. The Journal of biological chemistry 278, 3882-3890 (2003).

9. Rhee HS, Pugh BF. Genome-wide structure and organization of eukaryotic pre-initiation complexes. Nature 483, 295-301 (2012).

10. Mouaikel J, Verheggen C, Bertrand E, Tazi J, Bordonne R. Hypermethylation of the cap structure of both yeast snRNAs and snoRNAs requires a conserved methyltransferase that is localized to the nucleolus. Molecular cell 9, 891-901 (2002).

11. Seto AG, Zaug AJ, Sobel SG, Wolin SL, Cech TR. Saccharomyces cerevisiae telomerase is an Sm small nuclear ribonucleoprotein particle. Nature 401, 177-180 (1999).

12. Chapon C, Cech TR, Zaug AJ. Polyadenylation of telomerase RNA in budding yeast. RNA (New York, NY 3, 1337-1351 (1997).

13. Jamonnak N, Creamer TJ, Darby MM, Schaughency P, Wheelan SJ, Corden JL. Yeast Nrd1, Nab3, and Sen1 transcriptome-wide binding maps suggest multiple roles in post-transcriptional RNA processing. RNA (New York, NY 17, 2011-2025 (2011). 
14. Noel JF, Larose S, Abou Elela S, Wellinger RJ. Budding yeast telomerase RNA transcription termination is dictated by the Nrd1/Nab3 non-coding RNA termination pathway. Nucleic acids research $\mathbf{4 0}$, 5625-5636 (2012).

15. Zappulla DC, Cech TR. Yeast telomerase RNA: a flexible scaffold for protein subunits. Proceedings of the National Academy of Sciences of the United States of America 101, 10024-10029 (2004).

16. Coy S, Volanakis A, Shah S, Vasiljeva L. The Sm complex is required for the processing of non-coding RNAs by the exosome. PloS one $\mathbf{8}$, e65606 (2013).

17. Hass EP, Zappulla DC. Repositioning the Sm-Binding Site in Saccharomyces cerevisiae Telomerase RNA Reveals RNP Organizational Flexibility and Sm-Directed 3'-End Formation. Noncoding RNA 6, (2020).

18. Fisher TS, Taggart AK, Zakian VA. Cell cycle-dependent regulation of yeast telomerase by Ku. Nature structural \& molecular biology 11, 1198-1205 (2004).

19. Hass EP, Zappulla DC. The Ku subunit of telomerase binds Sir4 to recruit telomerase to lengthen telomeres in S. cerevisiae. Elife 4, (2015).

20. Garcia PD, et al. Stability and nuclear localization of yeast telomerase depend on protein components of RNase P/MRP. Nature communications 11, 2173 (2020).

21. Laterreur N, Lemieux B, Neumann H, Berger-Dancause JC, Lafontaine $\mathrm{D}$, Wellinger RJ. The yeast telomerase module for telomere recruitment requires a specific RNA architecture. RNA (New York, NY 24, 1067-1079 (2018).

22. Lemieux B, et al. Active Yeast Telomerase Shares Subunits with Ribonucleoproteins RNase P and RNase MRP. Cell 165, 1171-1181 (2016).

23. Wu H, Becker D, Krebber H. Telomerase RNA TLC1 Shuttling to the Cytoplasm Requires mRNA Export Factors and Is Important for Telomere Maintenance. Cell reports 8, 1630-1638 (2014).

24. Becker D, Hirsch AG, Bender L, Lingner T, Salinas G, Krebber H. Nuclear Pre-snRNA Export Is an Essential Quality Assurance Mechanism for Functional Spliceosomes. Cell reports 27, 3199-3214 e3193 (2019). 
25. Soheilypour M, Mofrad MRK. Quality control of mRNAs at the entry of the nuclear pore: Cooperation in a complex molecular system. Nucleus 9, 202-211 (2018).

26. Soheilypour M, Mofrad MRK. Regulation of the affinity between RNAbinding proteins and the export receptor enables nuclear basket proteins to distinguish and retain aberrant mRNAs. Scientific reports, 1-11 (2016).

27. Zander G, Krebber H. Quick or quality? How mRNA escapes nuclear quality control during stress. RNA Biol 14, 1642-1648 (2017).

28. Gallardo F, Olivier C, Dandjinou AT, Wellinger RJ, Chartrand P. TLC1 RNA nucleo-cytoplasmic trafficking links telomerase biogenesis to its recruitment to telomeres. The EMBO journal 27, 748-757 (2008).

29. Vasianovich $\mathrm{Y}$, Bajon $\mathrm{E}$, Wellinger RJ. Telomerase biogenesis requires a novel Mex67 function and a cytoplasmic association with the Sm(7) complex. Elife 9, (2020).

30. Ferrezuelo F, Steiner B, Aldea M, Futcher B. Biogenesis of yeast telomerase depends on the importin mtr10. Molecular and cellular biology 22, 6046-6055 (2002).

31. Bordonne R. Functional characterization of nuclear localization signals in yeast Sm proteins. Molecular and cellular biology 20, 7943-7954 (2000).

32. Bischoff FR, Gorlich D. RanBP1 is crucial for the release of RanGTP from importin beta-related nuclear transport factors. FEBS Lett 419, 249-254 (1997).

33. Bischoff FR, Klebe C, Kretschmer J, Wittinghofer A, Ponstingl H. RanGAP1 induces GTPase activity of nuclear Ras-related Ran. Proceedings of the National Academy of Sciences of the United States of America 91, 2587-2591 (1994).

34. Dasso M. The Ran GTPase: theme and variations. Curr Biol 12, R502508 (2002).

35. Bajon E, Laterreur N, Wellinger RJ. A Single Templating RNA in Yeast Telomerase. Cell reports 12, 441-448 (2015).

36. Mozdy AD, Cech TR. Low abundance of telomerase in yeast: implications for telomerase haploinsufficiency. RNA (New York, NY12, 1721-1737 (2006).

37. $\mathrm{Hu} \mathrm{Y}$, et al. Telomerase-null survivor screening identifies novel telomere recombination regulators. PLoS genetics 9, e1003208 (2013). 
38. Lundblad V, Blackburn EH. An alternative pathway for yeast telomere maintenance rescues est1- senescence. Cell 73, 347-360 (1993).

39. Teng SC, Zakian VA. Telomere-telomere recombination is an efficient bypass pathway for telomere maintenance in Saccharomyces cerevisiae. Molecular and cellular biology 19, 8083-8093 (1999).

40. Grandin N, Charbonneau M. Control of the yeast telomeric senescence survival pathways of recombination by the Mec1 and Mec3 DNA damage sensors and RPA. Nucleic acids research 35, 822838 (2007).

41. Hood JK, Silver PA. Cse1p is required for export of Srp1p/importinalpha from the nucleus in Saccharomyces cerevisiae. The Journal of biological chemistry 273, 35142-35146 (1998).

42. Hawkins C, Friedman KL. Normal telomere length maintenance in Saccharomyces cerevisiae requires nuclear import of the ever shorter telomeres 1 (Est1) protein via the importin alpha pathway. Eukaryot Cell 13, 1036-1050 (2014).

43. Gill T, Aulds J, Schmitt ME. A specialized processing body that is temporally and asymmetrically regulated during the cell cycle in Saccharomyces cerevisiae. The Journal of cell biology 173, 35-45 (2006).

44. Perederina A, Esakova O, Quan C, Khanova E, Krasilnikov AS. Eukaryotic ribonucleases P/MRP: the crystal structure of the P3 domain. The EMBO journal 29, 761-769 (2010).

45. Chen $\mathrm{H}$, et al. Structural Insights into Yeast Telomerase Recruitment to Telomeres. Cell 172, 331-343 e313 (2018).

46. Matera AG, Wang Z. A day in the life of the spliceosome. Nature reviews 15, 108-121 (2014).

47. Grandin N, Damon C, Charbonneau M. Cdc13 prevents telomere uncapping and Rad50-dependent homologous recombination. The EMBO journal 20, 6127-6139 (2001).

48. McEachern MJ, lyer S. Short telomeres in yeast are highly recombinogenic. Molecular cell 7, 695-704 (2001).

49. Teixeira MT, Arneric M, Sperisen P, Lingner J. Telomere length homeostasis is achieved via a switch between telomerase- extendible and -nonextendible states. Cell 117, 323-335 (2004). 
901

902

903

904

905

906

907

908

909

910

911

912

913

914

915

916

917

918

919

920

921
50. Lei EP, Krebber H, Silver PA. Messenger RNAs are recruited for nuclear export during transcription. Genes \& development 15, 17711782. (2001).

51. Zander G, et al. mRNA quality control is bypassed for immediate export of stress-responsive transcripts. Nature 540, 593-596 (2016).

52. Mattaj IW. Cap trimethylation of $U$ snRNA is cytoplasmic and dependent on U snRNP protein binding. Cell 46, 905-911 (1986).

53. Lund MK, Guthrie C. The DEAD-box protein Dbp5p is required to dissociate Mex67p from exported mRNPs at the nuclear rim. Molecular cell 20, 645-651 (2005).

54. Tieg B, Krebber H. Dbp5 - From nuclear export to translation. Biochimica et biophysica acta 1829, 791-798 (2013).

55. Lendvay TS, Morris DK, Sah J, Balasubramanian B, Lundblad V. Senescence mutants of Saccharomyces cerevisiae with a defect in telomere replication identify three additional EST genes. Genetics 144 , 1399-1412 (1996).

56. Lundblad V, Szostak JW. A mutant with a defect in telomere elongation leads to senescence in yeast. Cell 57, 633-643 (1989). 


\section{Figure legends}

923 Figure 1. The longer precursor of TLC1 binds the Sm-ring in the cytoplasm. (A) RIP

924 experiments were carried out with GFP-tagged Smb1 from wild type cells. One

925 example IP of Smb1 is shown on western blots. Aco1 served as a negative control.

926 (B) Smb1 binds to TLC1. The Smb1 co-precipitated RNA was used as a template in 927 qPCRs for $T L C 1$. For this (and all following IPs carried out in this study), the amount 928 of the eluted RNA was related to the RNA present in each lysate normalized to the 929 mitochondrial $21 \mathrm{~S}$ rRNA and compared to no tag. $n=4$. (C) A western blot shows an 930 example IP of the precipitated Smb1 protein from the RIP experiment shown in (D).

931 (D) Smb1 cannot bind to TLC1 when its nuclear export is prevented. The Smb1 co932 precipitated RNA was used as a template in qPCRs for TLC1 in the indicated strains, 933 shifted to $37^{\circ} \mathrm{C}$ for $1 \mathrm{~h} . n=3$. (E) $T L C 1$ accumulates in the cytoplasm of cells in

934 which the Sm-ring is not properly assembled. FISH-experiment of a Cy3-labeled 935 probe (red) targeting TLC1 is shown in wild type cells and a strain in which the Sm936 ring is not assembled trough mutation of $S M B 1$ and $S M D 1$ after glucose induced 937 expression repression. The DNA is stained with DAPI. $n=3$ (F) Scheme of the $\sim 1300$ 938 nucleotide long immature TLC1 and the primer positions for the amplification of the 939 total and the immature TLC1 molecules. (G) Western blot showing an example of a

940 Smb1 IP used in Fig. 1H and I in RIP experiments. (H) Blocking nuclear re-import of

941 TLC1 increases the amount of the total TLC1. RIP experiments and subsequent 942 qPCRs were carried out to show the total TLC1 in the indicated strains. $n=3$ (I)

943 Blocking nuclear re-import of TLC1 increases the amount of the immature TLC1.

944 RIP-experiments were carried out and subsequent qPCR results of the immature $945 T L C 1$ in the indicated strains is shown. $n=3(\mathrm{~J})$ Western blot showing an example of 946 a Cbp20 IP used in Fig. 1K for RIP experiments. (K) Immature TLC1 binds to 
947 Cbp20. The Cbp20 co-precipitated RNA was used as a template in qPCRs for

948 immature TLC1. RPL8A served as positive control. $n=3$

949

950 Figure 2. Cse1 is a novel nuclear import factor for $T L C 1$. (A) TLC1 mislocalizes to

951 the cytoplasm in cse1 mutants. A FISH-experiment for TLC1 (red) is shown in the

952 indicated strains that were shifted to the indicated non-permissive temperatures. $n=3$

953 (B) CSE1 and MTR10 genetically interact. Serial dilutions of the indicated strains

954 were spotted onto full medium agar plates and incubated at the indicated

955 temperatures. (C) RIP experiments were carried out with GFP-tagged Mtr10 and

956 Cse1 from wild type cells. One example IP is shown on a western blot. Hem15 served

957 as a negative control. (D) Cse1 binds to TLC1. The Cse1 co-precipitated RNA was

958 used as a template in qPCRs for total TLC1. $n=3$. Mtr10 served as a positive control.

$959 n=4$. (E) RIP-experiments were carried out in the indicated mutant strains. A

960 western blot of an example IP is shown. Aco1 served as a negative control. (F)

961 Binding of total TLC1 to Smb1 decreases in csel-1 and cse1-1 mtr10 cells. RIP-

962 experiments and subsequent qPCRs were carried out. $n=4(\mathrm{G})$ Binding of immature

963 TLC1 to Smb1 increases in cse $1-1$ and cse1-1 mtr $10 \Delta$ cells. RIP-experiments and

964 subsequent qPCRs were carried out. $n=4(\mathrm{H})$ The ratio of the Smb1-bound immature

965 versus total $T L C 1$ increases in $\operatorname{cse} 1-1 \mathrm{mtr} 10 \Delta$. The ratios were calculated from the

966 experiments shown in F and G. $n=4$ (I-K) The immature form of $T L C 1$ accumulates

967 in nuclear re-import mutants. The RNA was isolated from the indicated strains after a

$9681 \mathrm{~h} 15 \mathrm{~min}$ temperature shift to the non-permissive temperature. Subsequent qPCRs

969 were carried out with primers that detect either all TLC1 forms (total TLC1) (I) or

970 only the unprocessed form (immature $T L C 1)(\mathrm{J})$. (K) The ratio of immature to total

971 TLC1 increases in the import mutants. The ratios were calculated from the 
experiments shown in A and B. $m$ tr 10- $1 n=3$. cse $1-1 n=6$ and $\operatorname{cse} 1-1 m$ tr $10 \Delta n=5$

973

974 Figure 3. Loading of the Est and Pop proteins occurs in the cytoplasm. (A) Nuclear

975 GFP-tagged Est1 mislocalizes to the cytoplasm in cse1-1 cells. (B) A wild type strain

976 is shown without a GFP tagged protein with identical microscopy settings as shown

977 in (A). (C) Nuclear Pop1 localization is disturbed in mutants affecting TLC1

978 expression or its localization. $n=3$. (D) Western blot of the Pop1-GFP IP is shown in

979 the indicated strains. Grx4 served as a negative control. (E) Pop1 binding to TLC1 is

980 decreased in an export mutant. The Pop1-bound RNA from the several IP, one of

981 which is shown in D, was analyzed in qPCRs $n=3$. (F) Western blot of the Pop1-

982 GFP IP is shown in the indicated strains. Grx4 served as a negative control. (G) Pop1

983 binding to TLC1 is increased in an import mutant. The Pop1-bound RNA from the

984 several IP, one of which is shown in F, was analyzed in qPCRs. $n=3$.

985

986 Figure 4. Both nuclear import receptors contact TLC1 at the Sm-ring. (A) Mtr10 does

987 not interact with the Pop-protein complex. A western blot of co-IPs of GFP-tagged

988 Pop1 with myc-tagged Mtr10 is shown. Nop1 served as a washing control $n=3$ (B)

989 Mtr10 does not interact with the Est protein complex. A western blot of a co-IP of

990 GFP-tagged Est1 with myc-tagged Mtr10 is shown. Hem15 served as negative

991 control. $n=3$ (C) Mtr10 does not interact with the Yku protein complex. A western

992 blot of a co-IP of myc-tagged Mtr10 with Yku70 is shown. $n=3$ (D) Mtr10 interacts

993 with the Sm-ring. A western blot of a co-IP of GFP-tagged Smb1 with myc-tagged

994 Mtr10 is shown. Aco1 served as a negative control. $n=3$

995

996 Figure 5. Mutation of CSE1 results in a Type I like survivor phenotype. (A) Scheme 
997 of the Y-amplification and location of the probe that was used for the southern blot.

998 (B) The cse1-1 mutation leads to the amplification of the telomeric Y-element. XhoI

999 digested genomic DNA of the indicated strains was used for the southern blot. The

1000 chromosome ends were detected with a digoxygenin labeled probe. (C) Plasmid

1001 encoded CSE1 recues the csel-1 phenotype. XhoI digested genomic DNA of the 1002 indicated strains was used for the southern blot. The chromosome ends were detected 1003 with a digoxygenin labeled probe (Fig. 5A). (D) TLC1 localization is not altered in 1004 the srp1-31 mutant. FISH expermiments show no mislocalization of TLC1 in srp1-31 1005 after shift to $37^{\circ} \mathrm{C}$ for $1 \mathrm{~h} . \mathrm{n}=3$.

1007 Figure 6. Processing and TMG-capping of TLC1 occurs in the nucleus upon TLC1 re-import. (A) Unprocessed TLC1 accumulates in import factor mutants. A Western blot of a nucleo-cytoplasmic fractionation experiment is shown for the indicated 1010 strains. The nuclear Nop1 protein and the cytoplsasmic Zwf1 protein served as 1011 controls for successful isolation of the cytoplasmic fraction. Strains were shifted to 16 ${ }^{\circ} \mathrm{C}$ for $1 \mathrm{~h} 15 \mathrm{~min}$ prior to the experiments. $n=5$ (B) qPCRs of the fractionation experiments shown in A reveals an accumulation of the unprocessed TLC1 in the import factor mutants at the permissive termperature. $n=5$ (C) Western blot showing an example of a Np13 IP used in Fig. 1E in the RIP experiments. (D) TLC1 binds to

$1016 \mathrm{Npl3}$. The Npl3 co-precipitated RNA was used as a template in qPCRs for TLC1 and 1017 Hem15 as positive control. $n=4$ (E) Trimming of TLC1 is mediated by the nuclear exosome after nuclear re-import. The RNA was isolated from the indicated strains 1019 after shifting them to $37^{\circ} \mathrm{C}$ for $2 \mathrm{~h}$. Subsequently, qPCRs were carried out that 1020 determined the amount of the total TLC1 and its immature, longer precursor. Mex6710215 and rrp6 $\operatorname{mex67-5} n=4$. $\operatorname{Rrp} 6 \Delta n=8$ (F) TMG-capping occurs after nuclear TLC1 
re-import. The amount of TMG-capped TLC1 was determined by TMG-co-IPs and

1024 the black line indicates the amount of the precipitated non-TMG-capped RNAs

1025 resembling the base line for TMG-capping. Tgs $1 \Delta$ and $m \operatorname{tr} 10 \Delta n=4$. Cse1-1 and cse1-1 $m \operatorname{tr} 10 \Delta n=3$.

1027

Figure 7. Model for the compartmental stepwise maturation of TLC1. The longer precursor of TLC1 is transcribed in the nucleus and immediately exported into the cytoplasm upon binding of the export receptor Mex67-Mtr2 and the karyopherin

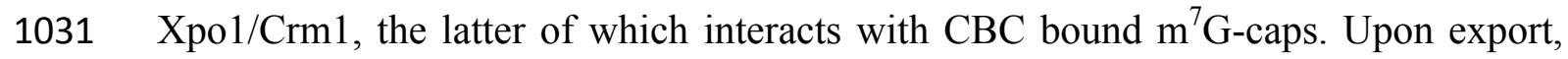

1032 Mex67 and Xpo1/Crm1 are displaced and the Sm-ring, the Est- and the Pop-proteins assemble on the immature $T L C 1$ in the cytoplasm. Subsequently, this RNP is reimported back into the nucleus via Mtr10 and Cse1, both of which contact TLC1 via its Sm-ring. Thus, nuclear re-import can only occur after RNP formation including 1036 the Sm-ring and therefore resembles an important quality control checkpoint. In the nucleus, the import receptors dissociate and TLC1 is trimmed up to the Sm-ring by the nuclear exosome. Finally TMG-capping occurs in the nucleolus assisted by Smb1,

1039 which interacts with Tgs1. This step terminates shuttling, because export receptors 1040 cannot be loaded anymore. The matured holoenzyme subsequently acts in telomere 1041 maintenance. 
bioRxiv preprint doi: https://doi.org/10.1101/2021.04.30.442090; this version posted April 30, 2021. The copyright holder for this preprint

(which was not certified by peer review) is the author/funder, who has granted bioRxiv a license to display the preprint in perpetuity. It is made available under aCC-BY-ND 4.0 International license.

Hirsch_Fig. 1

A

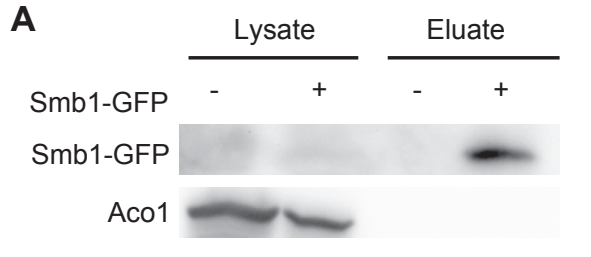

D

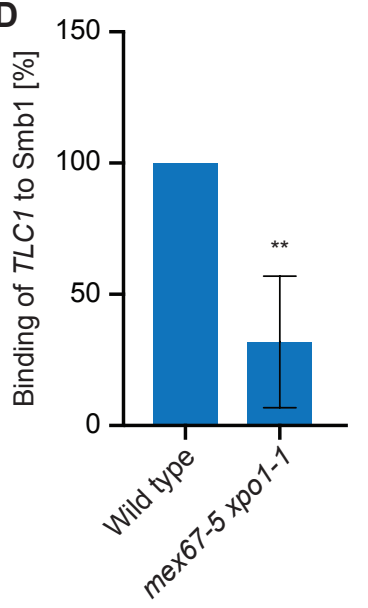

B

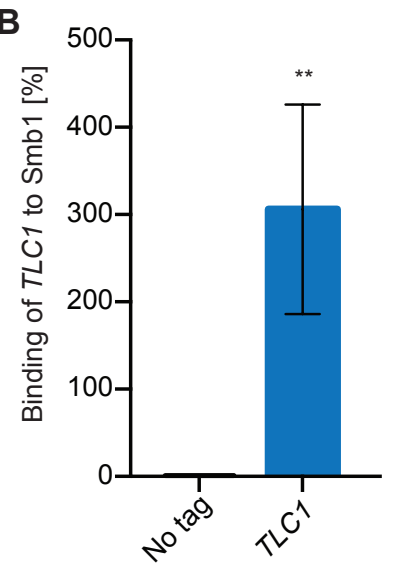

C

C

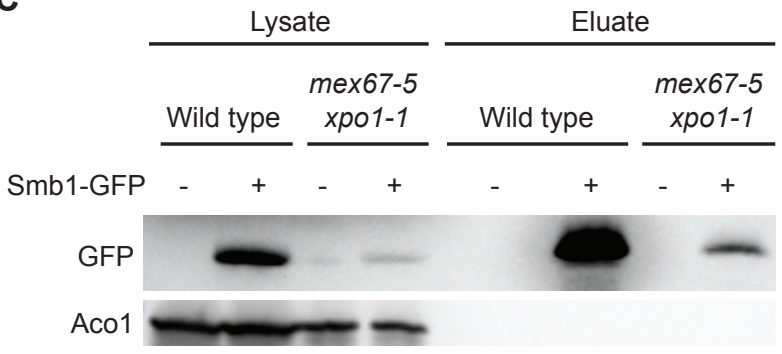

$\mathbf{F}$

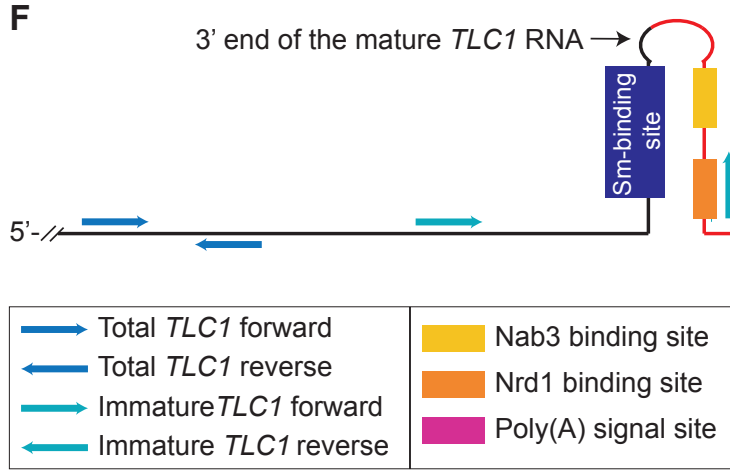

2h 4\% Glucose

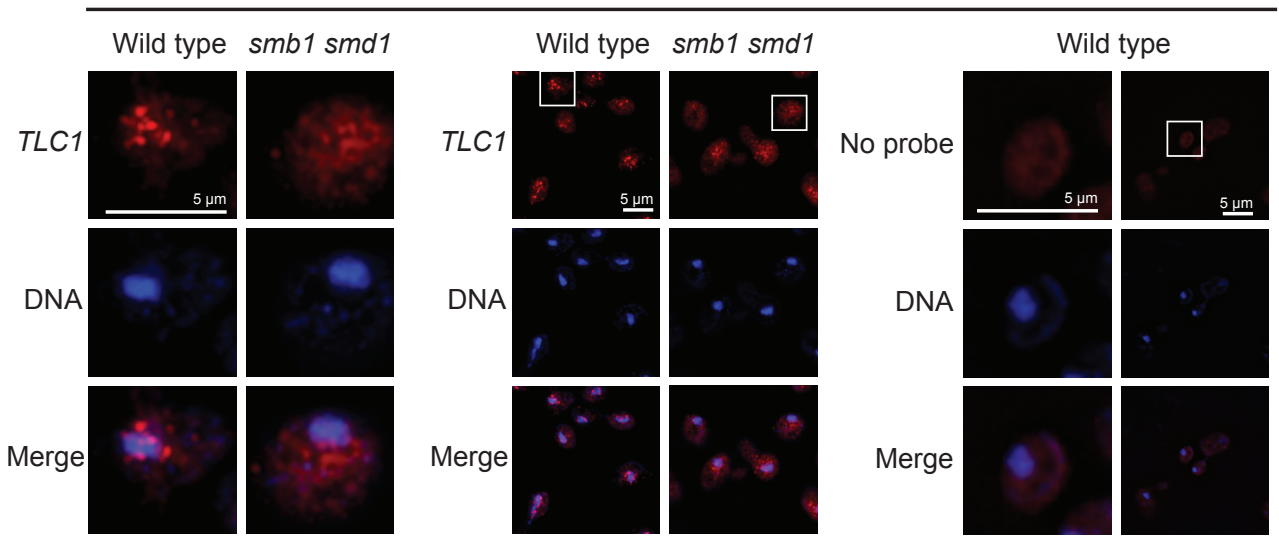

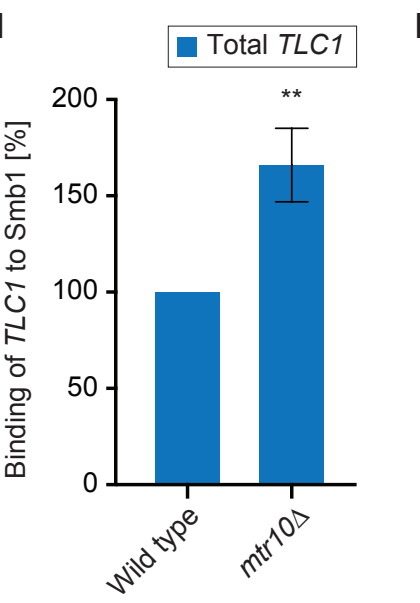

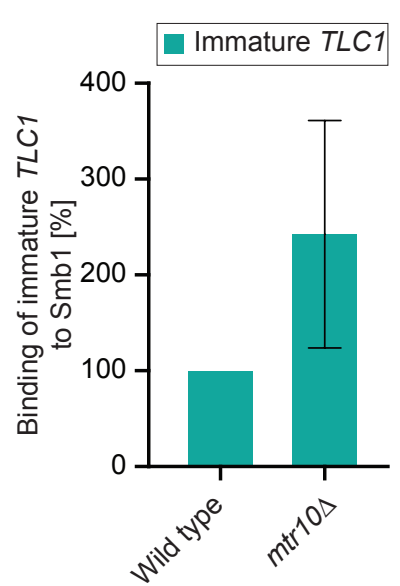

J

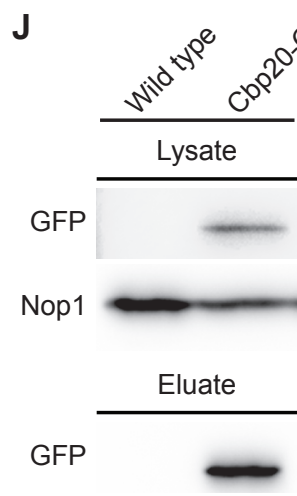

Nop1
G

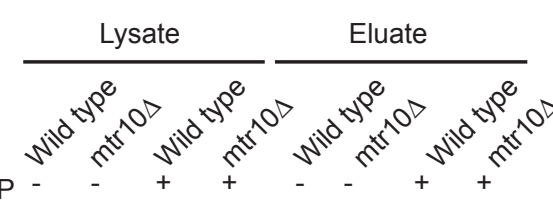

Smb1-GFP

GFP

Aco1
End for poly $(\mathrm{A})^{+}$addition 
bioRxiv preprint doi: https://doi.org/10.1101/2021.04.30.442090; this version posted April 30, 2021. The copyright holder foHihrspfeprin Fig. 2

(which was not certified by peer review) is the author/funder, who has granted bioRxiv a license to display the preprint in perpetuity. It is

A aCC-BY-ND 4.0 Interanational ligene
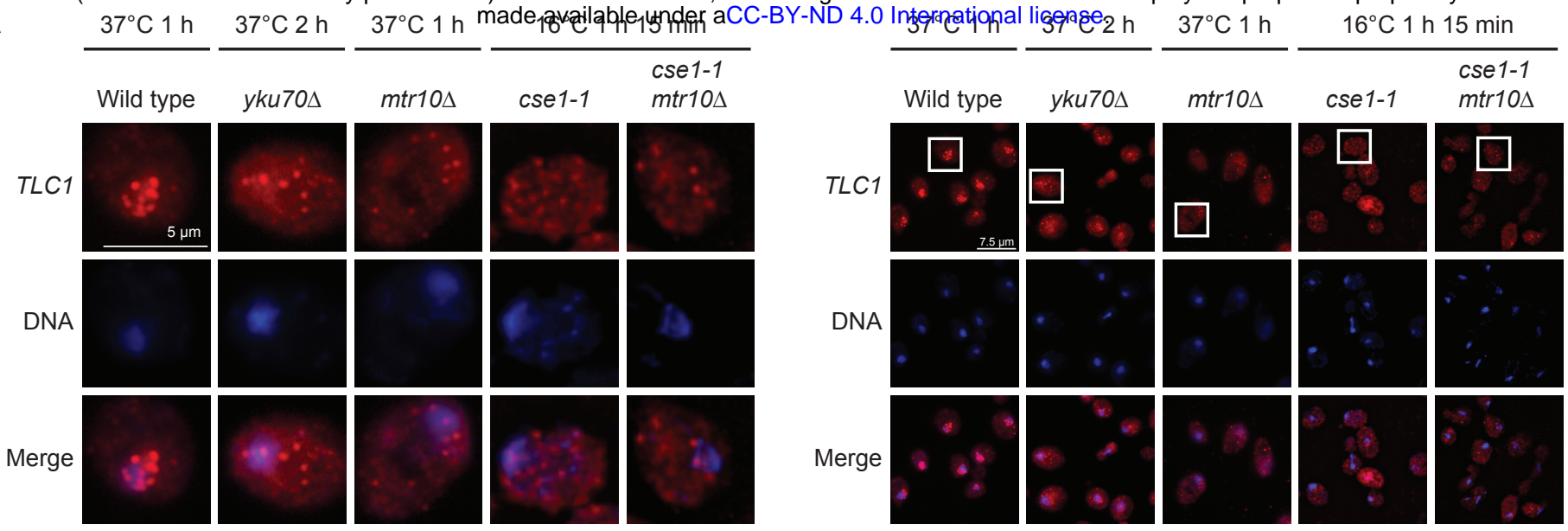

B

\begin{tabular}{|c|c|c|c|c|}
\hline 3 days & \multicolumn{4}{|c|}{2 days } \\
\hline $16^{\circ} \mathrm{C}$ & $20^{\circ} \mathrm{C}$ & $25^{\circ} \mathrm{C}$ & $30^{\circ} \mathrm{C}$ & $35^{\circ} \mathrm{C}$ \\
\hline 10 & 0 & . & & \\
\hline
\end{tabular}

C

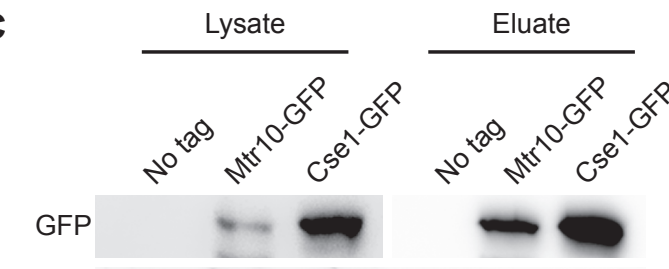

cse1-1 mtr10

cse1-1

$m \operatorname{tr} 10 \Delta$

Hem15
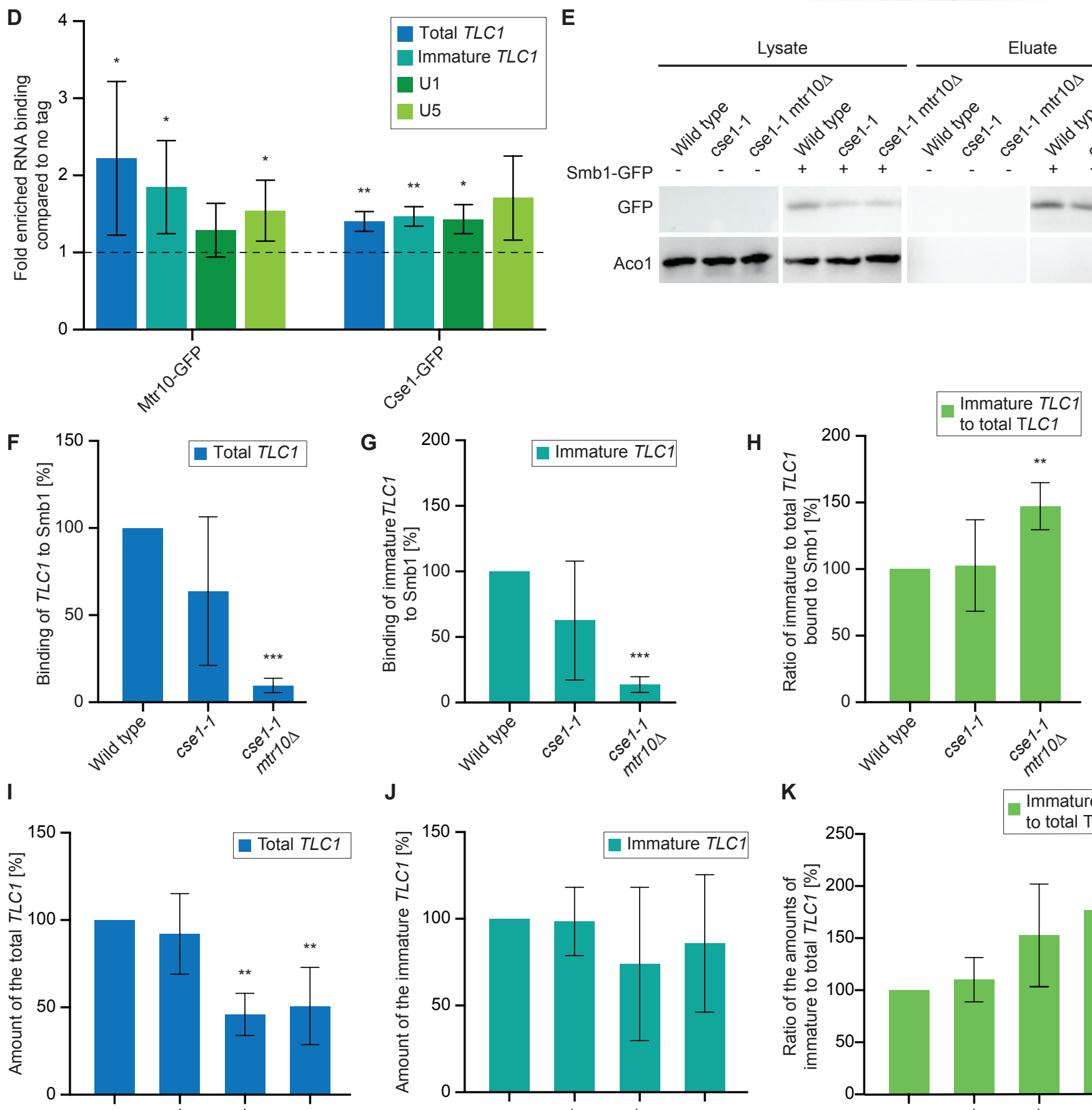

$\mathbf{J}$
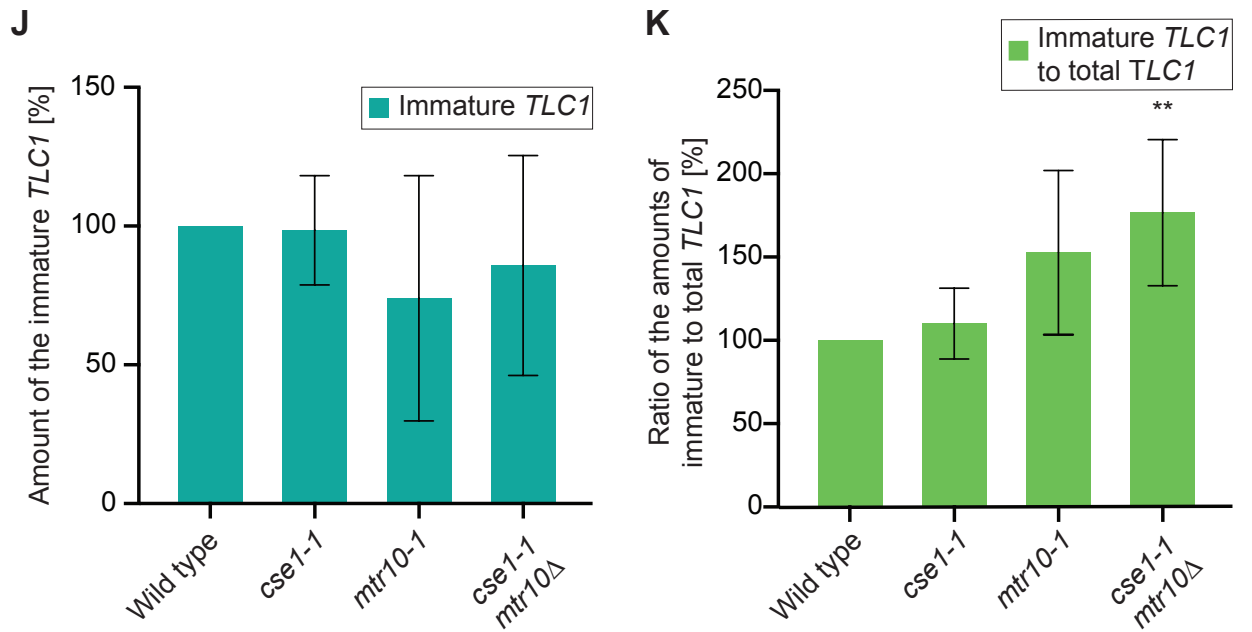

Lysate

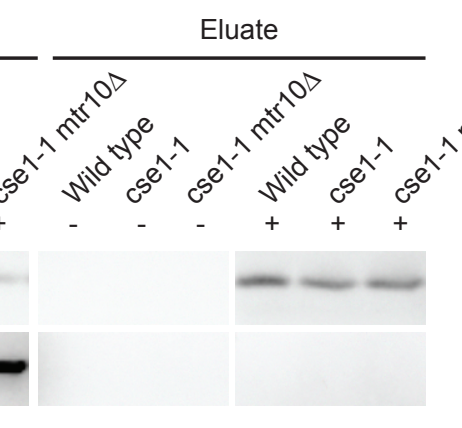

Smb1-GFP

GFP

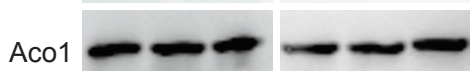


bioRxiv preprint doi: https://doi.org/10.1101/2021.04.30.442090; this version posted April 30, 2021. The copyright holder for this preprint

(which was not certified by peer review) is the author/funder, who has granted bioRxiv a license to display the preprint inf \$pnsthy. Filig. 3

A

Est1-GFP

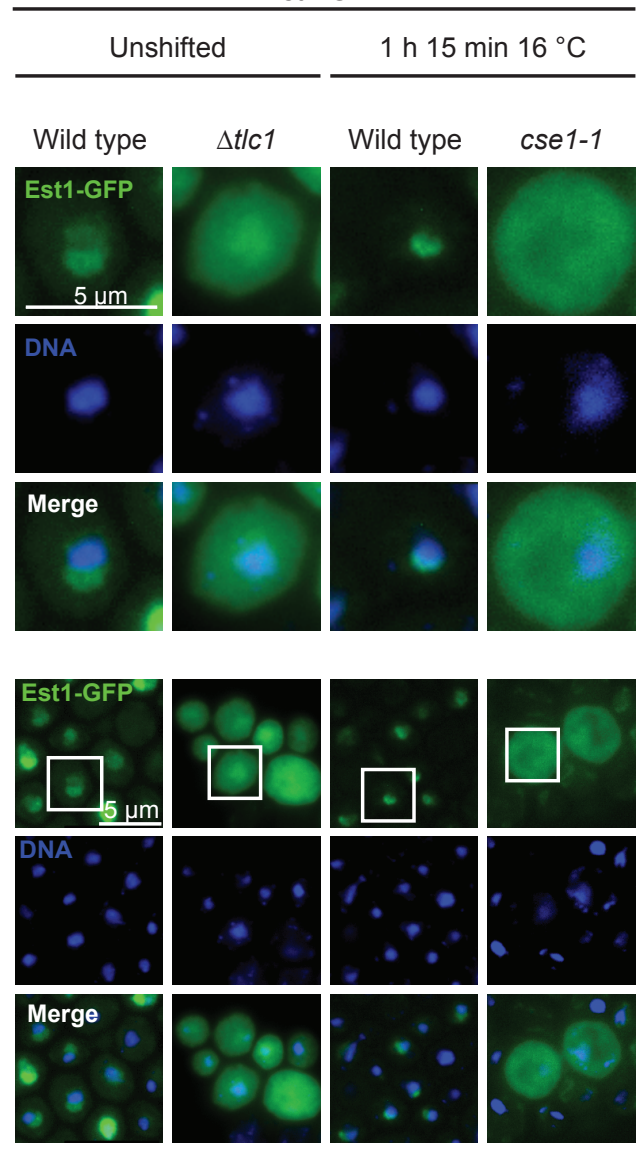

B

Wild type

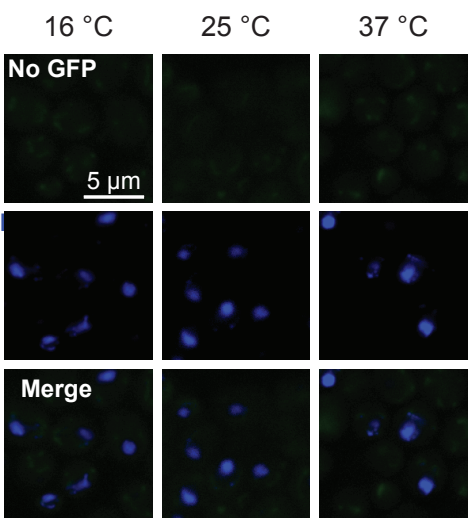

F

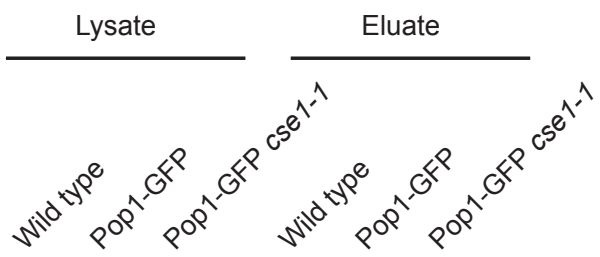

GFP

Grx4
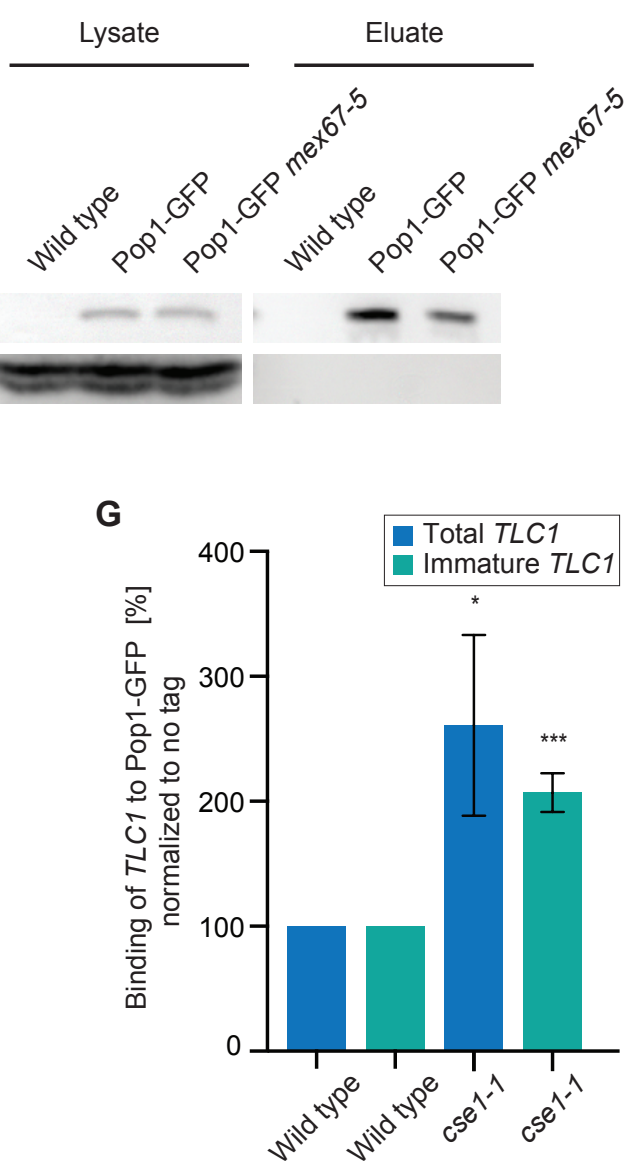

Pop1-GFP

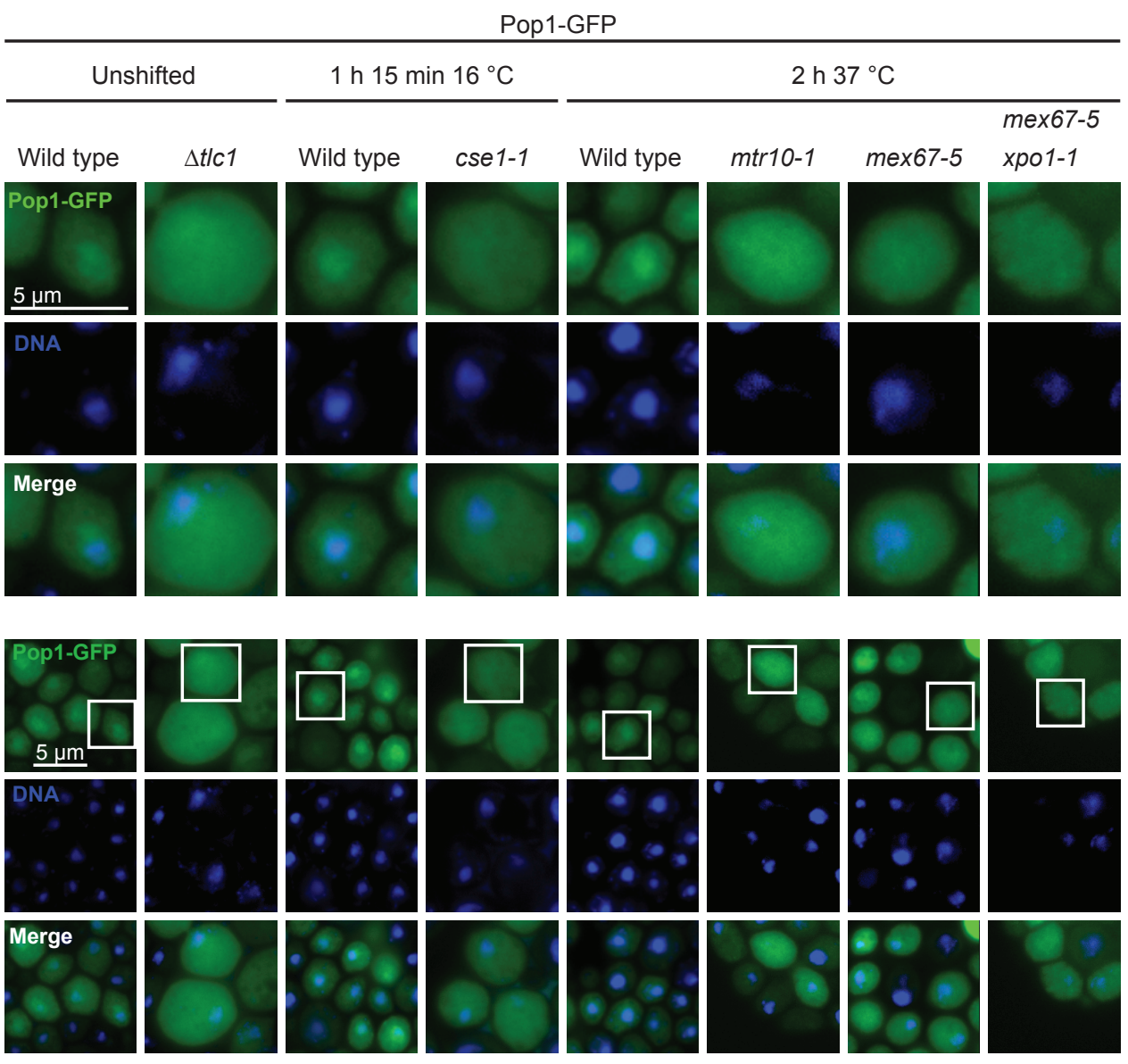

D

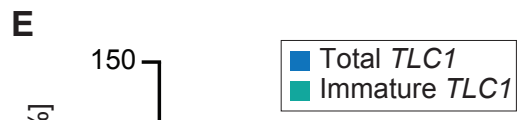

GFP

Grx4

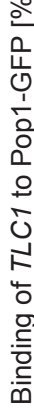

荇

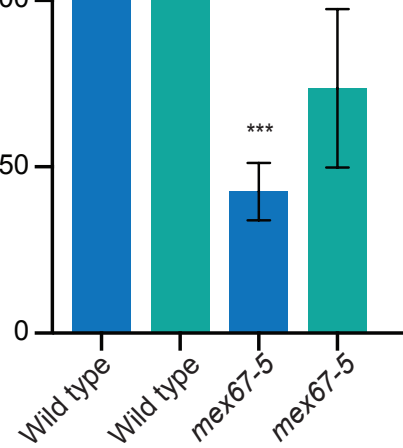


bioRxiv preprint doi: https://doi.org/10.1101/2021.04.30.442090; this version posted April 30, 2021. The copyright holder for this preprint

(which was not certified by peer review) is the author/funder, who has granted bioRxiv a license to display the preprint in perpetuity. It is made available under aCC-BY-ND 4.0 International license.

\section{Hirsch_Fig. 4}

A

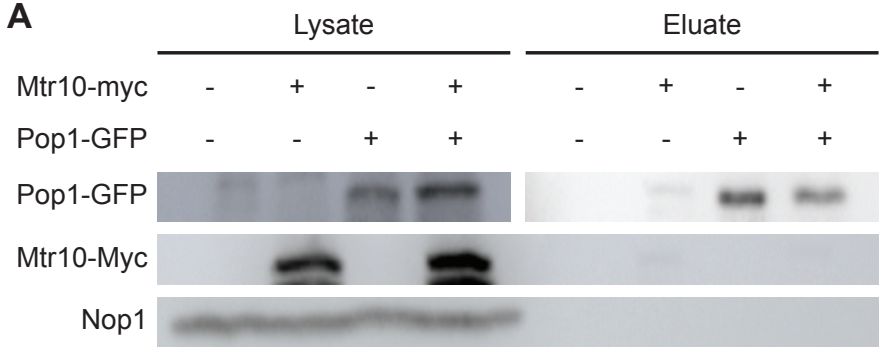

B

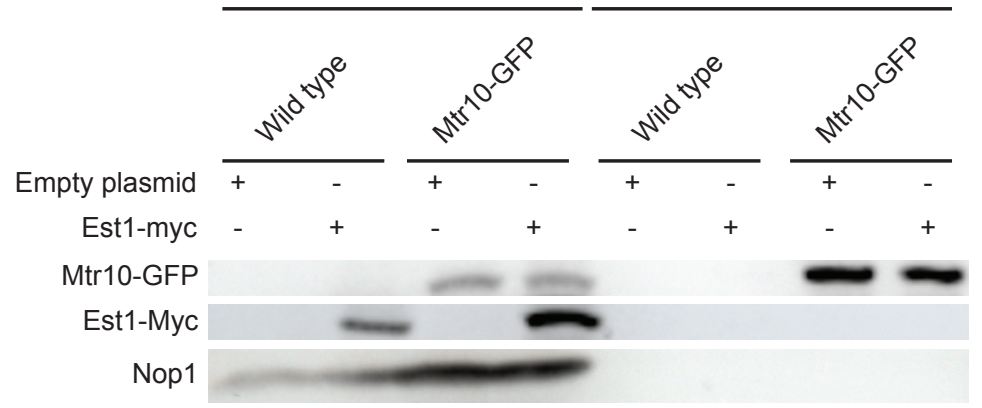

C

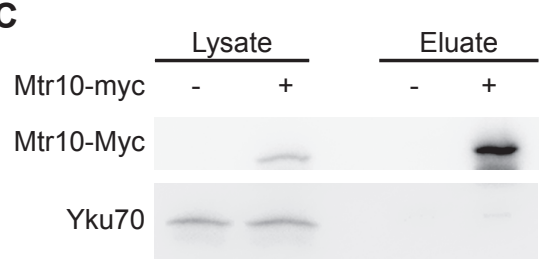

Hem15
D

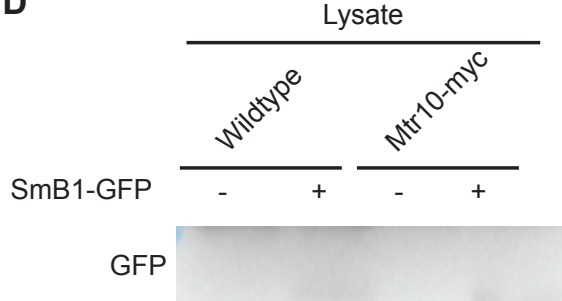

Mtr10- myc

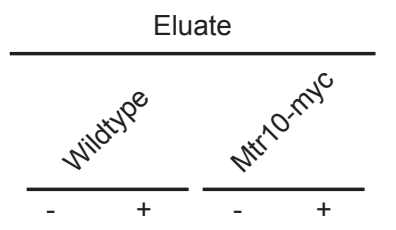

Aco1 
bioRxiv preprint doi: https://doi.org/10.1101/2021.04.30.442090; this version posted April 30, 2021. The copyright holder for this preprint

(which was not certified by peer review) is the author/funder, who has granted bioRxiv a license to display the preprint in perpetuity. It is made available under aCC-BY-ND 4.0 International license.

Hirsch_Fig. 5

A

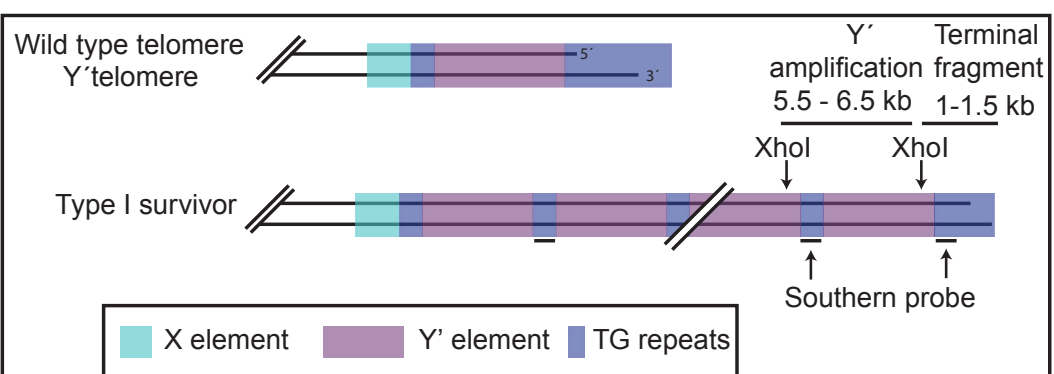

C
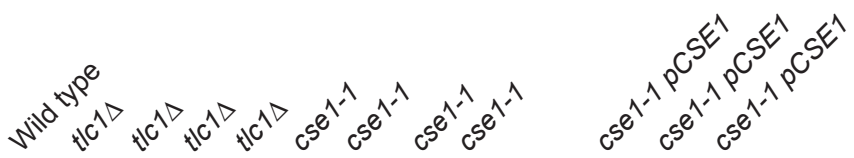

$\leftarrow Y^{\prime}$ amplification

$\leftarrow$ Terminal fragment

$1,3 \mathrm{~kb}$
$\begin{array}{lll}0 & 0 & 1\end{array}$
Number of restreaks

D

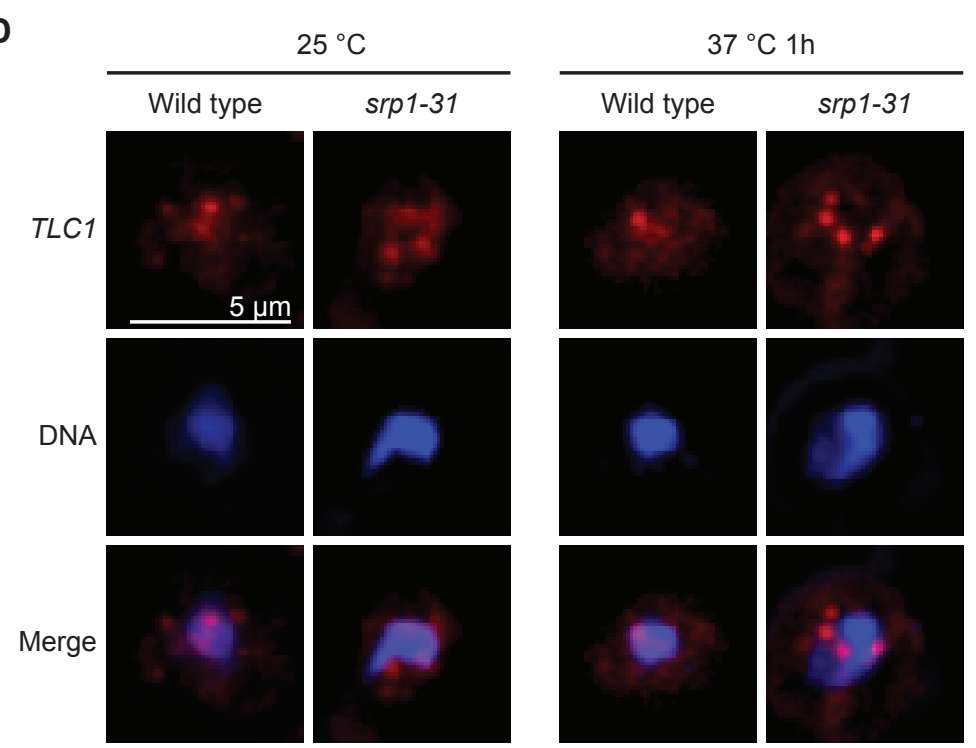

B

$5 \mathrm{~kb}$

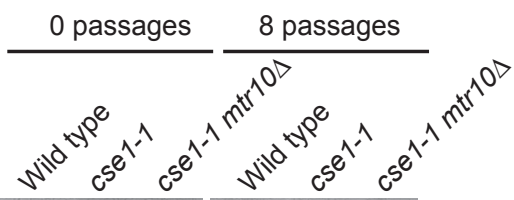

$\leftarrow Y^{\prime}$ amplification

$1,3 \mathrm{~kb}$

$\mathrm{kb}$

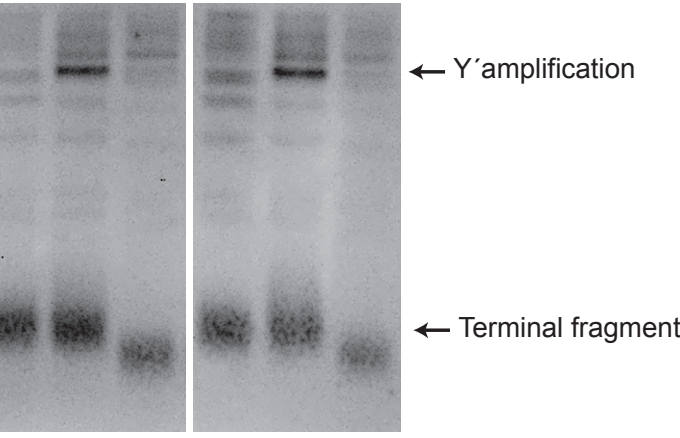

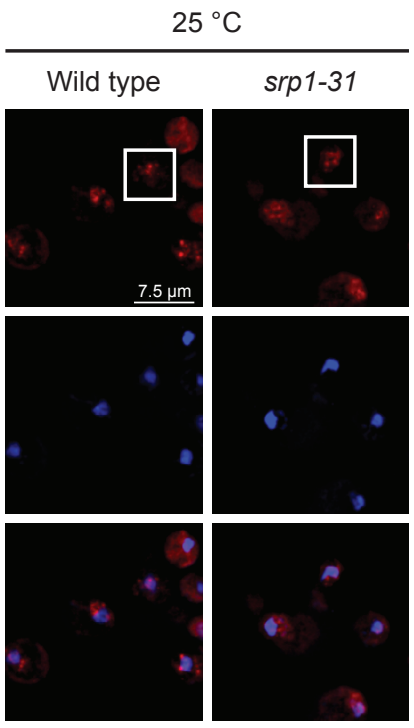

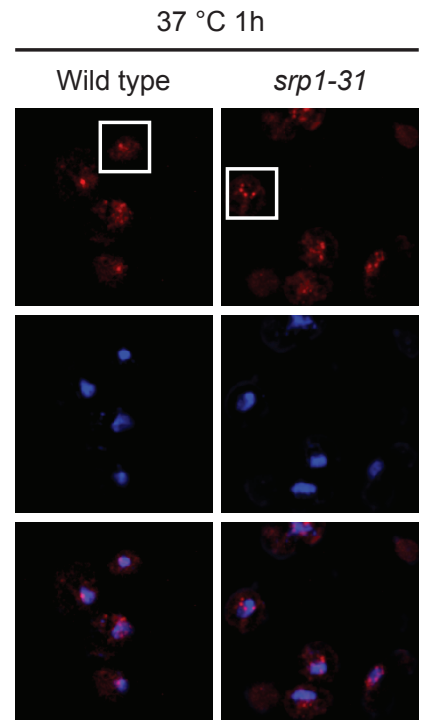


bioRxiv preprint doi: https://doi.org/10.1101/2021.04.30.442090; this version posted April 30, 2021. The copyright holder for this preprint

(which was not certified by peer review) is the author/funder, who has granted bioRxiv a license to display the preprint in perpetuity. It is made available under aCC-BY-ND 4.0 International license.

Hirsch_Fig. 6

A

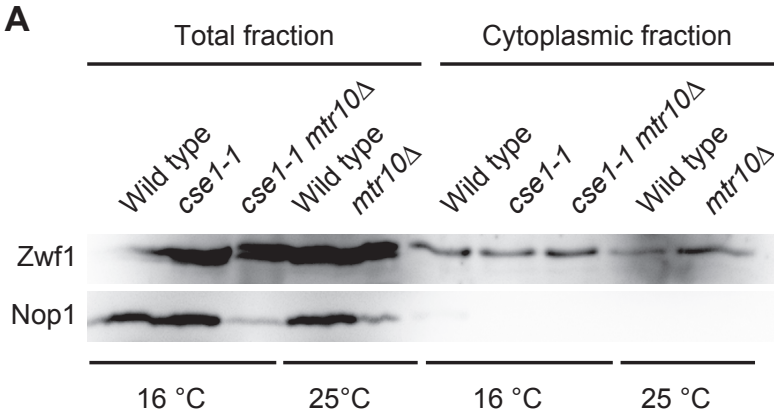

D

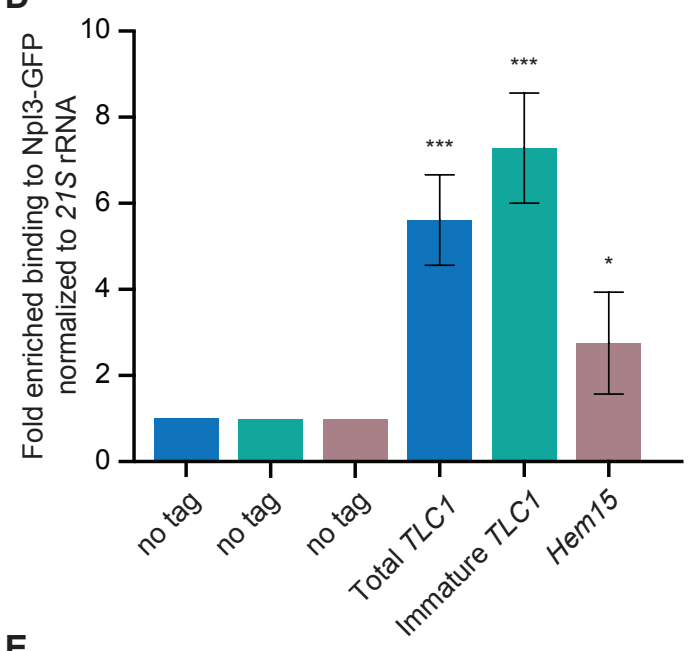

E

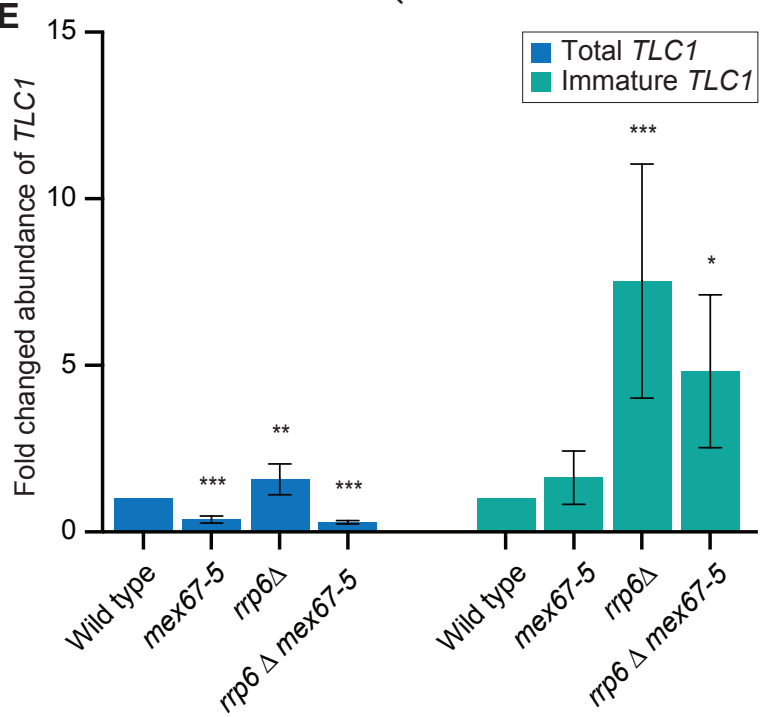

B

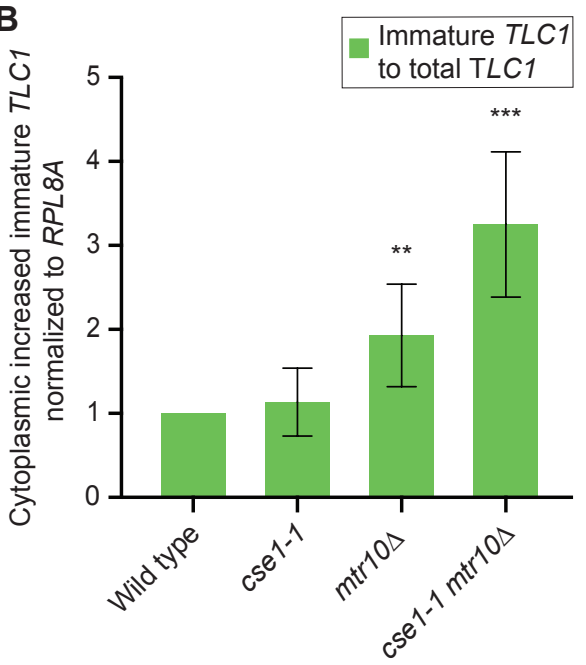

C

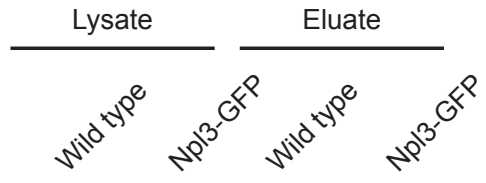

GFP

Hem15

F

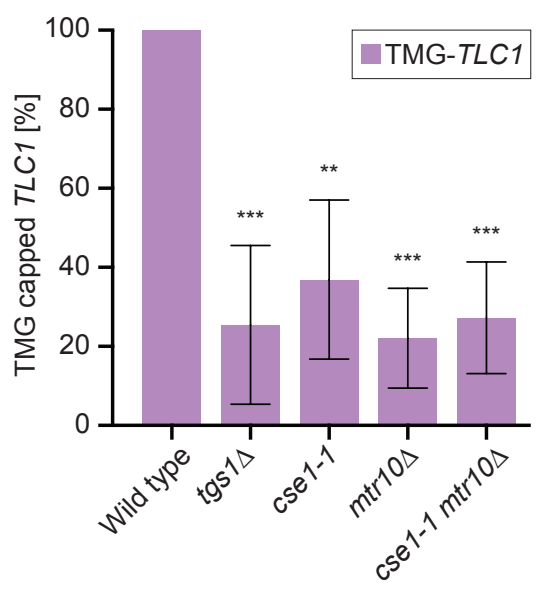




\section{Supplementary information to:}

\section{Unraveling the compartmental stepwise maturation of the yeast} telomerase

Anna Greta Hirsch ${ }^{1}$, Daniel Becker ${ }^{2}$, Jan-Philipp Lamping ${ }^{1}$ and Heike Krebber ${ }^{1 *}$

${ }^{1}$ Abteilung für Molekulare Genetik, Institut für Mikrobiologie und Genetik, Göttinger

Zentrum für Molekulare Biowissenschaften (GZMB), Georg-August Universität Göttingen,

Göttingen, Germany

${ }^{2}$ Current address: Philipps-Universität Marburg, Klinik für Dermatologie und Allergologie,

Baldingerstraße, D-35043 Marburg

"Correspondence: heike.krebber@biologie.uni-goettingen.de 
bioRxiv preprint doi: https://doi.org/10.1101/2021.04.30.442090; this version posted April 30, 2021. The copyright holder for this preprint (which was not certified by peer review) is the author/funder, who has granted bioRxiv a license to display the preprint in perpetuity. It is made available under aCC-BY-ND 4.0 International license.

\section{Supplementary Tables}

Supplemental Table 1. Yeast strains used in this study. Related to Figures 1-6

\begin{tabular}{|c|c|c|}
\hline Number & Genotype & Source \\
\hline HKY36 & 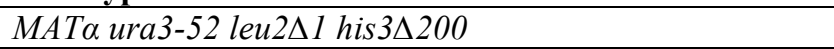 & 1 \\
\hline HKY 37 & 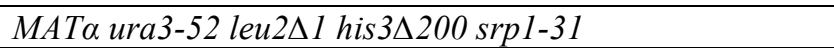 & 2 \\
\hline HKY46 & MATa ura3-52 lys2-301 ade2 mtr10-1 & 3 \\
\hline HKY208 & MAT $\alpha$ ura3-52 ade2-101 his3-11,15, trp1- $\Delta 901$ cse1-1 & 4 \\
\hline HKY316 & 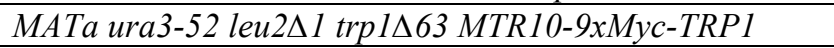 & This study \\
\hline HKY380 & MATa his $3 \Delta 1$ leu $2 \Delta 0$ met $12 \Delta 0$ ura $3 \Delta 0$ npl3::KanMX4 & Euroscarf \\
\hline HKY644 & $\begin{array}{l}\text { MAT } \alpha \text { ade2, his3, leu2, trp1, ura3 mex67::HIS3 } \\
\text { pUN100-mex67-5 (LEU2, CEN) }\end{array}$ & 5 \\
\hline HKY1028 & 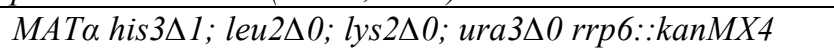 & Euroscarf \\
\hline HKY1073 & $\begin{array}{l}\text { MATa his } 3 \Delta 1 \text {; leu } 2 \Delta 0 ; \text { met } 15 \Delta 0 ; \text { ura } 3 \Delta 0 ; \\
\text { yKu70::kanMX4 }\end{array}$ & Euroscarf \\
\hline HKY1193 & 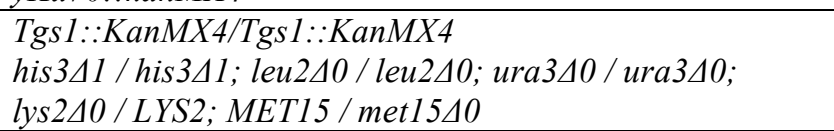 & Euroscarf \\
\hline HKY1293 & 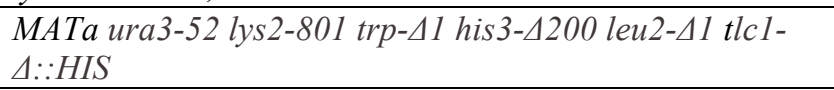 & 6 \\
\hline HKY1277 & 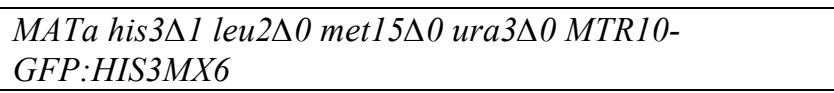 & 7 \\
\hline HKY1353 & $\begin{array}{l}\text { MATa ura3-52 mex67::HIS3 xpo1::TRP1 } \\
\text { pUN100 (CEN LEU2) mex67-5 xpo1-1::HIS3 }\end{array}$ & 8 \\
\hline HKY1596 & 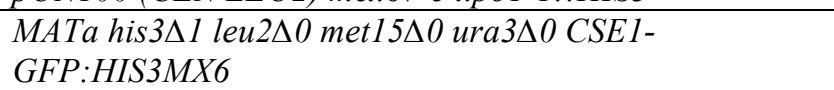 & 7 \\
\hline HKY1642 & 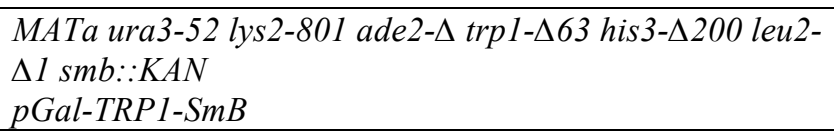 & 9 \\
\hline $\begin{array}{l}\text { HKY } 1645 \\
(s m b \text { smdl) }\end{array}$ & 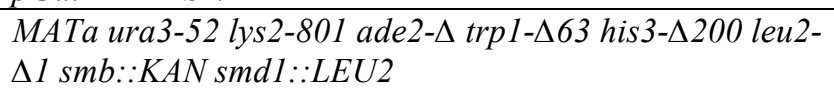 & 9 \\
\hline HKY 1689 & $\begin{array}{l}\text { MAT } \alpha \text { rrp6::kanMX4 mex67::HIS3 } \\
\text { pUN100-mex67-5 (LEU2, CEN) }\end{array}$ & 10 \\
\hline HKY1776 & $\begin{array}{l}\text { MATa mtr10:kanMX4 } \\
\text { lys ura leu his }\end{array}$ & This study \\
\hline HKY1799 & 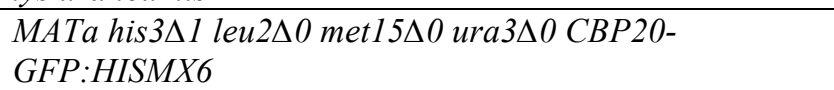 & Euroscarf \\
\hline HKY1815 & MATa ura leu Pop1-GFP:HisMX6 & Euroscarf \\
\hline HKY2087 & MATa his ura KAN cse1-1 mtr10:kanMX4 & This study \\
\hline HKY2093 & MATa ura cse1-1 Pop1-GFP:HisMX6 & This study \\
\hline HKY2101 & $\begin{array}{l}\text { MATa leu2A1 ura3-52 MTR10-9xMyc-TRP1 Pop1- } \\
\text { GFP:HisMX6 }\end{array}$ & This study \\
\hline HKY2153 & $\begin{array}{l}\text { MATa ura Pop1-GFP:HisMX6 mex67::HIS3 } \\
\text { pUN100-mex67-5 (LEU2, CEN) }\end{array}$ & This study \\
\hline
\end{tabular}

Supplemental Table 2. Plasmids used in this study. Related to Figures 1-6.

\begin{tabular}{|l|l|l|}
\hline Number & Genotype & Name \\
\hline pHK88 & CEN URA3 & 11 \\
\hline pHK206 & CEN URA CSE1 & This study \\
\hline pHK765 & CEN URA GFP-Np13 & 12 \\
\hline pHK1469 & CEN URA SmB-GFP & 13 \\
\hline pHK1483 & CEN URA GFP-POP1 & 14 \\
\hline pHK1589 & URA3 EST1-(Gly)6-(myc)12 & 15 \\
\hline pHK1606 & CEN URA pAdh-Est1-GFP & This study \\
\hline
\end{tabular}


bioRxiv preprint doi: https://doi.org/10.1101/2021.04.30.442090; this version posted April 30, 2021. The copyright holder for this preprint (which was not certified by peer review) is the author/funder, who has granted bioRxiv a license to display the preprint in perpetuity. It is made available under aCC-BY-ND 4.0 International license.

Supplemental Table 3. Oligonucleotides used in this study. Related to Figures 1-3, 5, 6. Forward primer (fw) and reverse primer (rev).

\begin{tabular}{|c|c|c|}
\hline Number & Sequence & Name \\
\hline HK1384 & 5'-GCGGAAGGAACCGTGTGTTC-3' & TLC1 immature $\mathrm{fw}$ \\
\hline HK1385 & 5'-GAAGCCTACCATCACCACACC-3' & Internal $T L C 1 \mathrm{fw}$ \\
\hline HK1386 & 5'-ACAGCGCTTAGCACCGTCTG-3' & Internal $T L C 1 \mathrm{rev}$ \\
\hline HK1539 & 5'-DIG-CCACCACACACACCCACACCC-3' & $\begin{array}{l}\text { 5' DIG labeled CA - } \\
\text { Telomeric repeat probe }\end{array}$ \\
\hline HK1598 & 5'-GGCCCCAGGTAAGAAAGTCG-3' & RPL8 fw \\
\hline HK1599 & 5'-GAAGGTTTCGGCAGCGGTG-3' & RPL8 rev \\
\hline HK1738 & 5'-TGCAAACTCCTTGGTCACAC-3' & U1 snRNA (snR19) fw \\
\hline HK1739 & 5'-CCAGGCAGAAGAAACAAAGG-3' & U1 snRNA (snR19) rev \\
\hline HK1761 & $\begin{array}{l}\text { 5'-CY3- } \\
\text { GCGCACACACAAGCATCTACACTGACACCAGCAT } \\
\text { ACTCGAAATTCTTTGG-CY3-3' }\end{array}$ & $T L C 1$ probe 1 \\
\hline HK1789 & $\begin{array}{l}\text { 5'-CY3- } \\
\text { CGATAAGATAGACATAAAGTGACAGCGCTTAGCA } \\
\text { CCGTCTGTTTGC-CY3-3' }\end{array}$ & TLC1 probe 2 \\
\hline HK1790 & $\begin{array}{l}\text { 5'-CY3- } \\
\text { CCTACTCGTATTTTTCTCTGTCACATCGTTCGATGT } \\
\text { ACGGGGCACATTTGG-CY3-5' }\end{array}$ & TLC1 probe 3 \\
\hline HK2154 & 5'-CCAGAACAATCCGTACACAAGG-3' & Hem15 fw \\
\hline HK2155 & 5'-GCAATTGTCTTCTGATACTTAGCAC-3' & Hem15 rev \\
\hline HK2859 & 5'-CAGCTTTACAGATCAATGGC-3' & U5 snRNA (snR7-L) fw \\
\hline HK2860 & 5'-TATGGCAAGCCCACAGTAA-3' & U5 snRNA (snR7-L) rev \\
\hline HK3089 & 5'-AGTTACGCTAGGGATAACAGGG-3' & 21S rRNA fw \\
\hline HK3090 & 5'-TGACGAACAGTCAAACCCTTC-3' & 21S rRNA rev \\
\hline HK3513 & 5'-ACGCGCGATTTCTACAATAC-3' & TLC1 immature rev \\
\hline
\end{tabular}

\section{Supplementary references:}

1. Winston F, Dollard C, Ricupero-Hovasse SL. Construction of a set of convenient Saccharomyces cerevisiae strains that are isogenic to S288C. Yeast (Chichester, England) 11, 53-55 (1995).

2. Loeb JD, Schlenstedt G, Pellman D, Kornitzer D, Silver PA, Fink GR. The yeast nuclear import receptor is required for mitosis. Proceedings of the National Academy of Sciences of the United States of America 92, 7647-7651 (1995).

3. Liu Y, Guo W, Tartakoff PY, Tartakoff AM. A Crm1p-independent nuclear export path for the mRNA-associated protein, Npl3p/Mtr13p. Proceedings of the National Academy of Sciences of the United States of America 96, 6739-6744. (1999).

4. Taura T, Krebber H, Silver PA. A member of the Ran-binding protein family, Yrb2p, is involved in nuclear protein export. Proceedings of the National Academy of Sciences of the United States of America 95, 7427-7432 (1998).

5. Segref A, et al. Mex67p, a novel factor for nuclear mRNA export, binds to both poly(A)+ RNA and nuclear pores. The EMBO journal 16, 3256-3271 (1997).

6. Lubin JW, Tucey TM, Lundblad V. The interaction between the yeast telomerase RNA and the Est1 protein requires three structural elements. RNA (New York, NY 18, 1597-1604 (2012).

7. Huh W-K, et al. Global analysis of protein localization in budding yeast. Nature 425, 686-691 (2003). 
8. $\quad$ Brune C, Munchel SE, Fischer N, Podtelejnikov AV, Weis K. Yeast poly ( A ) -binding protein Pab1 shuttles between the nucleus and the cytoplasm and functions in mRNA export Yeast poly ( A ) -binding protein Pab1 shuttles between the nucleus and the cytoplasm and functions in mRNA export. Rna-a Publication of the Rna Society, 517-531 (2005).

9. Bordonne R. Functional characterization of nuclear localization signals in yeast Sm proteins. Molecular and cellular biology 20, $7943-7954$ (2000).

10. Zander G, et al. mRNA quality control is bypassed for immediate export of stress-responsive transcripts. Nature 540, 593-596 (2016).

11. Sikorski RS, Hieter P. A system of shuttle vectors and yeast host strains designed for efficient manipulation of DNA in Saccharomyces cerevisiae. Genetics 122, 19-27 (1989).

12. Hackmann A, Gross T, Baierlein C, Krebber H. The mRNA export factor Np13 mediates the nuclear export of large ribosomal subunits. EMBO reports 12, 1024-1031 (2011).

13. Becker D, Hirsch AG, Bender L, Lingner T, Salinas G, Krebber H. Nuclear Pre-snRNA Export Is an Essential Quality Assurance Mechanism for Functional Spliceosomes. Cell reports 27, 3199-3214 e3193 (2019).

14. Gill T, Aulds J, Schmitt ME. A specialized processing body that is temporally and asymmetrically regulated during the cell cycle in Saccharomyces cerevisiae. The Journal of cell biology 173, 35-45 (2006).

15. Tucey TM, Lundblad V. Regulated assembly and disassembly of the yeast telomerase quaternary complex. Genes \& development 28, 2077-2089 (2014). 